\title{
Yaşam Memnuniyeti ve İş Kalitesi iliş̧kisi: Doğrusal Regresyon Modelleri ile OECD Ülkelerinden Bulgular
}

\section{Life Satisfaction and Job Quality Relationship: Findings from the OECD Countries for Linear Regression Models}

\author{
Ayhan Görmüş ${ }^{1}$ (†, Simla Güzel ${ }^{2}$ ()
}

Öz

Bireyin bir bütün olarak yaşam koşullarından hoşnut olması anlamına gelen yaşam memnuniyetinin temel bileşenlerinden biri de, iş kalitesidir. Bu açıdan iş kalitesi, çalışanların kazancı ve iş güvencesinin yanı sıra, yaşam kalitesini etkileyen diğer unsurların bir bileşimini yansıtmaktadır. Özellikle 2008 Küresel Ekonomik Krizi sonrasında iş kalitesine ilişkin endişelerin artması, bazı akademik çevrelerin ve uluslararası örgütlerin iş kalitesine yönelik ilgisini artırmış ve iş kalitesi ölçümüne yönelik çeşitli çalışmalar yapılmıştır. Bu çalışmalardan biri de OECD’nin üç boyut ve dokuz göstergeden oluşan İş Kalitesi Çerçevesi'dir. Bu anlamda, OECD İş Kalitesi Çerçevesi kazanç kalitesi, işgücü piyasası güvencesi ve çalışma ortamının kalitesi olmak üzere üç temel boyutta yapılandırılmıştır. Bu açıdan, bu çalışma temel olarak, OECD ülkelerinin İş Kalitesi Çerçevesi verilerine basit ve çoklu doğrusal regresyon modelleri uygulayarak yaşam memnuniyeti skorları ve iş kalitesi göstergeleri arasındaki ilişkiyi incelemeyi amaçlamaktadır. Basit doğrusal regresyon sonuçları, daha yüksek yaşam memnuniyeti skoruna sahip OECD ülkelerinde, iş kalitesinin daha yüksek olduğunu göstermektedir. Ayrıca çoklu doğrusal regresyon analizi istihdam oranı, kazanç kalitesi, iş otonomisi ve öğrenme firsatları ile kariyer ilerleme firsatındaki artş̧ı ülkelerin yaşam memnuniyeti skorlarını farklı derecelerde yükseltebileceği sonucuna ulaşmıştr.

\section{Anahtar Kelimeler}

Yaşam Memnuniyeti, iş̧ Memnuniyeti, İ̧̧ Kalitesi, OECD Ülkeleri

1 Sorumlu Yazar: Ayhan Görmüş (Doç. Dr.), Tekirdağ Namık Kemal Üniversitesi, İktisadi ve İdari Bilimler Fakültesi, Çalışma Ekonomisi ve Endüstri İlişkileri Bölümü, Tekirdağ-Türkiye, agormus@nku.edu.tr ORCID: 0000-0002-6175-5381

2 Simla Güzel (Doç. Dr.), Tekirdağ Namık Kemal Üniversitesi, İktisadi ve İdari Bilimler Fakültesi, Maliye Bölümü, TekirdağTürkiye, simlaguzel@nku.edu.tr ORCID: 0000-0001-5249-8873

Atıf: Gormus, A. ve Guzel, S. (2021). Yaşam Memnuniyeti ve İş Kalitesi İlişkisi: Doğrusal Regresyon Modelleri ile OECD Ülkelerinden Bulgular. Journal of Social Policy Conferences, 81, 1-33. https://doi.org/10.26650/jspc.2021.81.975338 


\begin{abstract}
One of the basic components of life satisfaction, which means an individual satisfaction with their living conditions as a whole, is job quality. Therefore, job quality reflects a combination of employees' earnings and job security, as well as other factors affecting their quality of life. Especially after the 2008 Global Economic Crisis, increasing worries on job quality boosted the interest of some academic circles and international organizations on job quality, and various studies were conducted to measure job quality. One of these studies is the OECD's Job Quality Framework, consisting of three dimensions and nine indicators. Particularly, dimensions of OECD's Job Quality Framework are structured on earning quality, labor market insecurity, and work environment quality. Therefore, this study aimed to investigate the relationship between life satisfaction scores and job quality indicators by carrying out bivariate and multiple linear regression models to Job Quality Framework data from OECD countries. Bivariate linear regression results revealed that OECD countries with higher life satisfaction scores have a higher job quality. In addition, multivariate linear regression analysis concludes that increased employment rate, earning quality, job autonomy and learning opportunities, and career advancement opportunity may improve life satisfaction scores of countries at varying degrees.
\end{abstract}

\title{
Keywords
}

Life Satisfaction, Job Satisfaction, Job Quality, OECD Countries 


\section{Extended Summary}

The life satisfaction concept that is sometimes used synonymously with happiness, but is mostly regarded as a subjective well-being component, is used for philosophical and psychological happiness and well-being explanations. Generally, life satisfaction means an individual satisfaction with life or life condition or fulfillment of desires and needs as a whole.

Life satisfaction is affected by many objective and subjective factors. Objective factors consist of health, education, physical activity, immigration status, internet access, owning a home, living in rural or urban areas, and employment and economic disadvantages, whereas subjective factors are personal characteristics. Among the subjective factors, the quality of working life or job quality, consisting of a set of job characteristics, has a significant effect on life satisfaction since most people spend a significant part of their time and life at work. Therefore, job quality, which is one of the key components of individual life satisfaction, generally reflects a combination of employees' earnings and job security, as well as other factors affecting their quality of life. Thus, job quality is far more an employee-centered concept, as it reflects what is good for the employee rather than the employer or client.

The quality of the job does not only affect the life satisfaction of the individual and households, but also influences labor force participation, productivity, and overall economic performance. Therefore, subjective and objective approaches were developed to measure life satisfaction and working life quality. In the subjective tradition, which originates in 19th-century utilitarianism, a person's life satisfaction meets as far as one can satisfy his/her personal tastes or preferences. Objective approaches are related to the basic concepts of human needs and values, such as Maslow's hierarchy of needs theory, unlike the utilitarianism of classical economics theory. However, combining both subjective and objective approaches to measure job quality became increasingly more common.

Especially after the 2008 Global Economic Crisis, increasing worries on job quality boosted the interest of some academic circles and international organizations on job quality, and various studies were conducted to measure job quality. One of these studies is the OECD's Job Quality Framework, which consists of three dimensions and nine indicators. Therefore, OECD's Job 
Quality Framework dimensions are structured on earning quality, labor market insecurity, and work environment quality.

Some empirical studies examine the socio-economic and demographic factors of life satisfaction and happiness in Turkey; however, studies explaining the life satisfaction and job quality relationship are insufficient. Admittedly, in Turkey, studies on life satisfaction and happiness are highly valuable; however, discussing the relationship between job quality and life satisfaction is very interesting and valuable in the learning lessons for Turkey since Turkey (5.6) is among the OECD countries with one of the lowest life satisfaction scores. Therefore, this study aimed to examine the relationship between life satisfaction scores and job quality indicators by carrying out bivariate and multiple linear regression models to Job Quality Framework data from OECD countries.

Overall, the bivariate analysis results imply the examination of the relationship between life satisfaction scores and each job quality indicators in six dimensions that substantially varies by OECD countries. In addition, the findings point out that job quality is generally better for OECD countries with higher life satisfaction scores than OECD countries with lower life satisfaction scores. Moreover, while Switzerland, Iceland, Denmark, Sweden, Norway, Finland, Netherlands, and New Zealand have a relatively better performance in the relationship between life satisfaction and job quality indicators; Greece, Portugal, Hungary, and Turkey display a relatively worse performance. However, job quality indicators significantly differ among these OECD countries with similar life satisfaction scores. Therefore, bivariate linear regression results revealed a higher job quality in the OECD countries with higher life satisfaction scores. In addition, multivariate linear regression analysis reveals that an increased employment rate, earning quality, job autonomy and learning opportunities, and career advancement opportunity may improve life satisfaction scores of countries at varying degrees. 


\section{Yaşam Memnuniyeti ve İş Kalitesi İlişkisi: Doğrusal Regresyon Modelleri ile OECD Ülkelerinden Bulgular}

Yaşam memnuniyeti kavramı, mutluluk ve refahın felsefi ve psikolojik açıklamalarında oldukça sık kullanılmaktadır. Yaşam memnuniyeti bazen mutluluk ile aynı anlamda kullanıldığı gibi (Hall, 2014, s.157), çoğu zaman sübjektif iyi oluşun (subjective well-being) bir bileşeni olarak da kabul edilmektedir (Diener ve Suh, 1999, s.434; Diener, 2000, s.34; Diener vd., 1999, s.277; Pavot ve Diener, 2008, s.137). Bu açıdan yaşam memnuniyetini belirlemek için bireyin yaşamı bir bütün olarak değerlendirilmektedir. Örneğin hayatın önemli alanlarından iş memnuniyetinde, olumlu duygular ve ruh hali gibi pozitif etkilerin yanı sıra, olumsuz duygu ve ruh hali gibi negatif etkiler de dikkate alınmaktadır (Diener vd., 1999, s.276; Diener, 2000, s.34). Çünkü Diener' in (1984), (1999), (2000) de belirttiği gibi, bireyin yaşam memnuniyetini değerlendirirken özellikle, iş yaşamı, aile ve ev gibi yaşamın önemli etki alanları göz önünde bulundurulmalıdır. Diğer taraftan Keyes (2006), hedojenik sübjektif iyi oluşu bireyin mutlu ve yaşamından memnun olması olarak tanımlamaktadır. Bu tanımda mutluluk bireyin anlık duygularını belirtiyorken, yaşam memnuniyeti ise, daha uzun dönemli olumlu veya olumsuz duygularını ifade etmektedir (Keyes, 2006, s.395-396). Howell ve Howell'e (2008) göre, yaşam memnuniyeti ve mutluluk sübjektif iyi oluşun belirleyicileridir, fakat yaşam memnuniyeti daha bilişsel iken, mutluluk duygusal bir değerlendirmedir. Ancak farklı çalışmalarda bu kavramların birbirlerinin yerine de kullanıldığı görülmektedir. Bu açıdan, bu çalışmada kavramsal bir bütünlük sağlamak için sübjektif iyi oluşun bir bileşeni olarak yaşam memnuniyeti kavramı kullanılacaktır.

Latince bir kavram olan "satisfaction", (memnuniyet) "bir şeyi yapmak veya yeterli yapmak" anlamına gelmektedir. Yaşam memnuniyeti ise, kişinin yaşamından ve yaşam koşullarından hoşnut olduğu, mevcut yaşam koşullarını kabul ettiği ya da bir bütün olarak yaşamında isteklerinin ve ihtiyaçlarının yeterince karşılandığ 1 anlamına gelmektedir (Sousa ve Lyubomirsky, 2001, s.3). Bu bağlamda yaşam memnuniyeti, bireylerin yaşamlarıyla ilgili yaptıkları bilişsel bir değerlendirmedir (Diener ve Suh, 1997, s.200 ) ve biyolojik, psikolojik, ekolojik ve toplumsal faktörlerin tümü, yaşam memnuniyetine karmaşık şekillerde etki etmektedir (Kubiszewski vd., 2020, s.1). Diğer taraftan, yaşam memnuniyetini etkileyen pek çok sübjektif ve objektif faktör de bulunmaktadır. Objektif faktörlere sağl1k, eğitim, fiziksel aktivite, göçmenlik 
statüsü, internete ulaşım, ev sahibi olma, kırsal ya da kentsel kesimde yaşama, istihdam ve ekonomik dezavantajlar vb. örnek olarak verilebilir. Aynı zamanda kişisel özellikler gibi sübjektif faktörler de yaşam memnuniyeti üzerinde etkili olabilmektedir (Kubiszewskia, Zakariyyab ve Costanzaa, 2018, s.371). Yaşam memnuniyetini etkileyen en önemli sübjektif faktörlerden biri de bir dizi iş özelliğinden oluşan çalışma yaşamının kalitesi veya iş kalitesidir (Green, 2006, s.9). Bu anlamda bireysel yaşam memnuniyetinin temel bileşenlerinden biri olan iş kalitesi; genel olarak işgücünün kazancını, işle ilgili ekonomik güvencenin yanı sıra, iş ve ötesinde yaşam kalitesini etkileyen diğer unsurların bir bileşimini yansıtmaktadır (OECD, 2014, s.82). Bu bakımdan iş kalitesi daha çok çalışan merkezlidir, yani işveren ya da müşterinin ne isteyebileceğini değil, çalışan için neyin iyi olduğunu ifade etmektedir. Ancak, işverenin veya müşterinin istekleri de çalışanın yaşam memnuniyetini doğrudan veya dolaylı olarak etkileyebilmektedir (Green, 2006, s.9). İş kalitesi çalışma süresi, güvenlik ve sağlık, adil ücretler, nitelikleri geliştirme firsatlarının tanınması, iş-yaşam dengesi, cinsiyet eşitliği, iş memnuniyeti, tanınma ve sosyal güvenlik gibi çalışma koşullarından etkilenmektedir. Aynı zamanda örgütlenme özgürlüğü, işyerinde ve toplumda söz sahibi olabilmek de önem taşımaktadır. Son olarak, insan onurunu güvence altına almak ve ayrımcılı̆̆ı, zorla çalıştırmayı, insan ticaretini ve özellikle de çocuk işçiliğini ortadan kaldırmak da iş kalitesini etkilemektedir (UN, 2010, s.1).

İş kalitesi sadece bireyin ve hane halklarının yaşam memnuniyetini etkilemekle kalmaz, aynı zamanda işgücüne katılımı, verimliliği ve toplam ekonomik performans1 da etkilemektedir (OECD, 2014, s.82). Bu yüzden, yaşam memnuniyeti ve dolayısıyla iş yaşamının kalitesini ölçmeye yönelik sübjektif ve objektif yaklaşımlar geliştirilmiştir. Kökenleri 19.yy faydacılığına dayanan sübjektif geleneğe göre, bir kişinin yaşam memnuniyeti, kişisel zevklerini veya tercihlerini tatmin edebildiği ölçüde karşılanmaktadır. Yaşam memnuniyetiyle ilgili başlıca sübjektif yaklaşımlar arasında en önemlisi, işi yaklaşık olarak belirlenmiş belirli yükümlülüklerin (çalışma süreleri, çalışma çabası, görevler vb.) bir ücret paketi ve diğer faydalar karşısındaki değişimi olarak ele alan klasik iktisat düşüncesidir (Green, 2006, s.9). Bu anlamda klasik iktisat yaklaşımının önde gelen temsilcilerinden Adam Smith, herkes kaliteli işlerde çalışmayı tercih ettiğinden, daha az tercih edilen düşük kaliteli işlerin net cazibesinin artırılmasını telafi edici ücret farklılıkları teorisi ile açıklamaktadır (Elliot, 1997, s.309). İş yaşamının kalitesine ilişkin geliştirilen objektif 
yaklaşımlar ise, klasik iktisat yaklaşımının fayda anlayışından farklı olarak, bu yaklaşımların insan ihtiyacı ve değerinin temel kavramlarıyla ilgilidir. $\mathrm{Bu}$ açıdan, objektif yaklaşımlarda yüksek kaliteli çalışma ortamlarının özellikleri, Maslow'un ihtiyaçlar hiyerarşisi teorisi veya diğer benzer çerçeveler kullanılarak ele alınmaktadır (Green, 2006, s.12). Ancak iş kalitesinin ölçülmesinde hem sübjektif, hem de objektif yaklaşımların birleştirilmesi giderek daha yaygın hale gelmektedir. Bu kısmen, yaşam memnuniyeti ve mutluluk gibi sübjektif iyi oluş ölçümlerinin bireyin faydasını değerlendirmek için giderek daha fazla kullanıldığg ekonomi literatüründeki hâkim düşünceyi yansıtmaktadır. İş kalitesi ve işyerindeki refaha, iş memnuniyeti gibi objektif ölçütleri de dâhil etmek, geleneksel fayda yaklaşımının yanı sıra; ücretler ve çalışma süreleri gibi sübjektif ölçütler kullanmaya kıyasla, daha genel bir bakış açısı sağlamaktadır. "Mutluluk ekonomisi" literatüründe ulaşılan sonuçlar, insanların yalnızca ücret ve çalışma süreleri gibi sonuçları değil, aynı zamanda bu sonuçlara yol açan koşullar ve süreçleri de önemsediği anlamına gelen prosedürel fayda görüşüyle yakından ilişkilidir (Kauhanen ve Nätti, 2015, s.786). Diğer taraftan, Green (2006) iş kalitesinin temel bileşenleri, öncelikle anketlerdeki çalışanların bireysel değerlendirmeleri ile ölçülebilir olduğundan, herhangi bir kapsamlı ölçümün, sübjektif verilerin avantajlarından (örneğin, ilk elden bilgi) ve potansiyel sınırlamalarından (örneğin sosyal itibar önyargısı) etkilendiğini belirtmektedir.

Türkiye'de yaşam memnuniyeti ve mutluluğun sosyo-ekonomik ve demografik faktörlerini ampirik olarak inceleyen bazı çalışmaların (Gitmez ve Morcöl, 1994; Selim, 2008; Toker, 2012; Dumludağ, 2013; Ozben, 2013; Dumludağ, Gokdemir ve Giray Yakut 2016; Eren ve Aşıc1, 2017) yanı sıra, kısmi süreli istihdam ile iş kalitesi arasındaki ilişkiyi inceleyen (Görmüş, 2021) bir çalışma bulunmaktadır. Şüphesiz bu çalışmalar oldukça değerli olmakla birlikte, OECD ülkeleri arasında Türkiye'nin en düşük yaşam memnuniyeti skorlarından $(5,6)$ birine sahip olması bakımından, iş kalitesi ile yaşam memnuniyeti ilişkisini açıklayan çalışmaların eksik olduğu gözlenmektedir. $\mathrm{Bu}$ yüzden, yaşam memnuniyetini etkileyen faktörlerden biri olan iş kalitesinin incelenmesi ve yaşam memnuniyeti ile ilişkisinin tartışılması, oldukça ilginç ve değerli olacaktır. Bu bağlamda, Türkiye için dersler çıkarmanın yanı sıra, literatüre katkı yapmak amacıyla yapılan bu çalışma, OECD ülkeleri verilerini kullanarak, yaşam memnuniyeti skorları ile iş kalitesi göstergeleri arasındaki ilişkiyi basit ve çoklu doğrusal regresyon modelleriyle analiz etmeyi 
amaçlamaktadır. Bu çerçevede, çalışmanın geri kalan kısımları, yaşam memnuniyeti ile iş kalitesi ilişkinin değerlendirildiği "literatür incelemesi", akademik çevreler ve uluslararası örgütlerin geliştirdiği iş kalitesi göstergeleri, araştırma verileri ve analiz teknikleri ile elde edilen bulguların incelendiği "araştırma yöntemi" ve sonuçların tartışıldığı "sonuç" bölümlerinden oluşmaktadır.

\section{Literatür İncelemesi}

Bireysel yaşam memnuniyeti, bir dizi yaşam koşuluna bağlı olmakla birlikte, çoğu insan zamanının ve hayatının önemli bir bölümünü işte geçirdiği için çalışmak, insanların ekonomik ve sosyal yaşam koşullarını önemli ölçüde etkilemektedir (Clark, 2015, s.2). Bu açıdan bakıldığında, çalışmak sadece ekonomik değil, aynı zamanda psikolojik ve sosyolojik boyutları da olan bir aktivitedir. Bu anlamda çalışmak, her şeyden önce bir yaşam biçimidir ve çalışana toplumsal bir statü kazandırmanın yanı sıra, çalışanın yaşam memnuniyetini de artırmaktadır. Bu nedenle insanların sahip oldukları işler, yaşam memnuniyetlerinin en önemli belirleyicilerinden biridir (OECD, 2016, s.1).

Şüphesiz bireyin bir işe sahip olması, elbette onun yaşam standardını olumlu bir şekilde etkilerken (Green, 2006, s.14), işsiz kalması yaşam memnuniyetini önemli ölçüde düşürmektedir (Clark ve Oswald, 1994, s.658; Clark, 2015, s.2). Hatta birey bir süre işsiz kaldıktan sonra iş bulsa dahi, önceki yaşam memnuniyeti seviyesine tekrar ulaşamayabilir (Lucas vd., 2004, s. 8). Bu bağlamda Grün, Hauser ve Rhein (2010) çalışanın iş memnuniyeti, ücreti, sözleşme türü, çalışan ile işin gereksinimleri arasındaki uyum gibi göstergelerden oluşan iş kalitesini göz önünde bulundurarak, çok iyi bir işe sahip olunmasa bile, bir iş sahibi olmanın yaşam memnuniyetini olumlu etkilediği sonucuna ulaşmışlardır. Ayrıca işin ekonomik faktörlerinin dışında, çalışanların işyerinde eğitim almasının ve iş deneyimi kazanmasının da yaşam memnuniyeti açısından önemli olduğunun altı çizilmektedir. Ancak işler birden çok boyutta farkl11ık göstermekte ve çalışmayla ilişkili yaşam memnuniyeti, yani iş memnuniyeti, işten işe değişkenlik göstermektedir (Clark, 2015, s.2). Bu yönden bazı çalışanlar mevcut işlerinden memnunken, diğer bazılarının, mevcut işleri bireysel beklentilerini yeterince karşılamadığ için iş memnuniyeti düzeyleri daha düşük kalabilmektedir. $\mathrm{Bu}$ bağlamda işlerinden daha az memnun olanların hem işten çıkarılma, hem de işi bırakma olasılıkları daha yüksektir (Clark, 2001, s.238). Bu açıdan bakıldığında, 
işyerinde çalışan memnuniyetinin, iş kalitesi kavramı ve ilgili literatür ile yakından ilişkili olduğu söylenebilir (Kauhanen ve Nätti, 2015, s.785). Yani, iş memnuniyeti temel olarak, iş kalitesi ile de ifade edilmektedir (Clark, 2015, s.2). Bu anlamda çalışana bir dizi görevi yerine getirmek, işbirliği içinde diğer çalışanların yardımından yararlanmak ve kariyer ilerlemesi veya daha önemli görevler ve daha yüksek ücretler sunan başka işlere geçme olasılığı için belirli bir kabiliyet, yetenek, esneklik ve iş otonomisi imkânı sağlayan işler, yüksek kaliteli iş olarak tanımlanabilir. Amartya Sen'in değerlendirmeleri çerçevesinde türetilen bu yüksek kaliteli iş anlayışı özerklik, beceri ve sosyal ilişkilerin yanı sıra, işin mevcut ve olası maddi ödüllerine de odaklanan iş kalitesinin geleneksel sosyolojik boyutlarına vurgu yapmaktadır (Green, 2006, s.14).

İş kalitesi, bir çalışanın psikolojik, sosyal ve ekonomik refahı açısından oldukça önemli bir etken olmanın yanı sıra, toplumsal refahın ne kadar iyi olduğuna dair daha geniş bir sosyal sorunun da ayrılmaz bir parçasıdır (OECD, 2014, s.82). Bu açıdan, küreselleşme süreci, artan rekabet, teknolojik gelişmeler ve yaşlanan nüfus, işgücü piyasasında bir takım değişimlere yol açarak birçok gelişmiş ülkede tam zamanlı ve belirsiz süreli standart istihdam biçimleri, kısmi süreli ve geçici istihdam gibi standart dışı esnek istihdam biçimlerine dönüşmüştür. Böylece işgücü piyasasında yaşanan bu değişimler, çalışanların işsiz kalmasından veya kısmi süreli ya da geçici çalışmasından kaynaklanan sosyal risklerini artırmıştır. Ekonomik açıdan bakıldığında, standart dışı esnek çalışma biçimleri, dinamik işgücü piyasasının bir yan etkisi olarak görülse bile (Dooley ve Prause, 2004, s.9), genel olarak düşük verimli, düşük ücretli ve düşük vasıf gerektiren güvencesiz işlerin çalışanların yaşam memnuniyetini düşürdüğü kabul edilmektedir (Tam, 2010, s.9). Bu anlamda standart dışı işlerin kalitesiyle ilgili "iyi işler/kötü işler" gibi tematik ayrımlar da yapılmaktadır. Örneğin Tilly (1996) iyi işleri kötü işlerden ayırmak için ücretler, beceri, eğitim ve sorumluluk, iş gücü devri ve kariyer ilerlemesinden oluşan dört grup temel iş özelliğini incelemiştir. Öte yandan Kalleberg, Reskin ve Hudson (2000) ABD' de standart dışı istihdam ile “kötü iş” özelliklerine maruz kalma arasındaki ilişkiyi incelemiş ve ABD'deki standart dışı işlerin yaklaşık 1/7'sinin kötü iş olduğu sonucuna ulaşmışlardır. Kauhanen ve Nätti (2015) de gönülsüz geçici ve kısmi süreli çalışanların işveren tarafından sağlanan eğitim olanakları, kariyer firsatları, öğrenme ve işte gelişim, iş güvencesi ve iş özerkliği gibi iş kalitesi göstergeleri açısından, istisnasız bir şekilde daha düşük çalışma koşulları sunduğunu ileri sürmüştür. 
İş kalitesi bireyin yaşamı kadar, bir örgütün işleyişinin ve bir toplumun refahının birçok yönü ile de yakından ilişkilidir. Bu açıdan iş kalitesi, genellikle iş memnuniyeti ile ölçülmektedir, fakat iş memnuniyeti ile ilgili yargılar doğası gereği sübjektif değerlendirmelerdir (Kalleberg ve Vaisey, 2005, s.431-432). Geleneksel olarak endüstriyel psikoloji ve sosyolojinin önemli konularından biri olan iş memnuniyetinin, sübjektif de olsa, çalışanın işini bırakma ve işe devamsızlık gibi, objektif davranışları tahmin etmeye yardımcı olan bir takım bilgiler sunduğu kabul edilmektedir (Green, 2006, s.152). Ayrıca iş memnuniyetinin insanların yaşam standartlarını artıran bir etkisi de bulunmaktadır. Örneğin Yazıcıŏlu ve Kubilay (2017) iş memnuniyetinin yaşam memnuniyetini olumlu etkilediği ve yaşam memnuniyeti yüksek olanların iş memnuniyetinin de yüksek olduğu sonucuna ulaşmışlardır. Diğer taraftan Diener ve Tay (2012) kariyer memnuniyeti, örgütsel bağlılık ve özellikle de iş memnuniyetinin yaşam memnuniyeti ile ilişkili olduğunu gösteren çok sayıda çalışmanın bulunduğunu belirtmektedir. Bu anlamda, Lent ve Brown (2006; 2008) yaşam memnuniyetinin kariyer memnuniyeti, hedefler doğrultusunda ilerleme ve kişilik özelliklerinden doğrudan etkilendiğini ileri sürmektedir. Ayrıca Vietnam verilerini kullanan Ahn ve arkadaşları (2018) da mutlak ve nispi gelirlerin yanı sıra, etkin ücret ve eğitim politikası gibi insan kaynakları uygulamalarının iş memnuniyeti üzerinde etkisinin bulunduğu sonucuna ulaşmıştır. Ancak iş memnuniyeti sadece işin sağladığı yaşam memnuniyetine değil, aynı zamanda kişinin normalde elde etmeyi beklediği yaşam memnuniyetine de bağlıdır. Yani, aynı iş için işten sınırlı beklentileri olan birinin iş memnuniyeti, işten daha yüksek beklentileri olan başka bir kişiden daha yüksek olabilir. Bu açıdan, iş memnuniyeti kavramı, çalışanların işlerine karşı verdiği tüm duygusal tepkileri yeterince kapsamamaktadır. Diğer taraftan bir iş, çalışana keyifli ve endişeden uzak bir çalışma ortamı sağlıyorken, bazı teşviklerden yoksun bırakabilir. Kısacası, bireyler arasında veya gruplar arasında ya da ülkeler arasında iş memnuniyeti düzeylerinin karşılaştırılması geçerlilik eksikliği nedeniyle oldukça zordur (Green, 2006, s.152-153).

İş memnuniyeti, çalışanların yaşam memnuniyetinin önemli bir parçası olmasının yanı sıra, çalışan verimliliğini artırabilmesi açısından firmaların da ilgisini çekmektedir. Bu anlamda Harter, Hayes ve Schmidt (2002) iş memnuniyeti ve çalışan bağlılığının kârlılık, verimlilik, işgücü devri ve işe devamsızlık dâhil firma performansıyla ilişkili olduğunu ileri sürmektedir. Ayrıca etkin ücret teorisine göre, işgücü verimliliği açık bir şekilde firmanın 
iş kalitesine yaptığı yatırıma bağlıdır. Bu bağlamda, en azından belirli düzeydeki ücret artışları, firma kârlarını da yükseltecektir. Bu yüzden, iş memnuniyeti insan kaynakları departmanlarının özellikle üzerinde durduğu bir konudur. Çünkü çalışanların işinden memnun olması, işyerinde çalışmaya devam etme olasılıklarını artırmakta ve ayrıca performanslarını da olumlu yönde etkilemektedir (Sami vd., 2011, s.121). Bu anlamda iş memnuniyetindeki artışın çalışanların performanslarını olumlu etkileyeceğini savunan çok sayıda çalışma (Harrison, Newman ve Roth, 2006; Whitman, Van Rooy ve Viswesvaran, 2010; Zelenski, Murphy ve Jenkins, 2008; Buhai, Cottini, ve Westergârd-Nielsen, 2008; Harter, Hayes ve Schmidt, 2002) bulunmaktadır. Bu sonuçlar, iş kalitesi açısından çalışanlar ve firmalar arasında potansiyel bir çıkar uyumu olduğuna işaret etse de, her iki tarafın çıkarlarının birbiriyle tamamen uyumlu olduğu söylenemez. Her şeyden önce, iş kalitesini artırmanın firmalara bir bedeli vardır ve iş kalitesini sağlamak, çoğu firma için oldukça maliyetlidir. Bu yatırımın daha yüksek verimlilik ve daha düşük işgücü devri gibi geri dönüşleri olsa bile, firmaların iş kalitesini sağlama maliyetlerinin daha yüksek iş kalitesi getirilerinden daha ağır basacağı bir nokta vardır. Bu açıdan iş kalitesini yükselten firmalar, bu noktayı aştıklarında iflasla karşılaşabilirler (Clark, 2015, s.2).

\section{İş Kalitesinin Ölçümüne İlişkin Geliştirilen Ölçekler}

İş kalitesi kavramı, özünde çalışan refahı kavramıyla ilişkili olsa da, iş kalitesi ve insanların mutluluk ve yaşam memnuniyetine ilişkin ölçüm çabaları ile paralel olarak gelişmiştir. Bu yönüyle mutluluk ve yaşam memnuniyetinin hem ekonomik kaynaklarla, hem de insanların yaşamlarının ekonomik olmayan yönleriyle ilgisi olduğu ve dolayısıyla doğası gereği çok boyutlu bir yapıyı temsil ettiği konusunda genel bir fikir birliği vardır (OECD, 2014, s.83-84). Yani, literatürde iş kalitesinin değerlendirilmesinde kullanılan iş ve çalışan özelliklerinin temel göstergelerinin ve çerçevelerinin değişkenliğini açıç̧a gösteren, birçok boyut bulunmaktadır (Kauhanen ve Nätti, 2015, s.785). Bu anlamda iş kalitesi, refahı ve yaşam kalitesini etkileyen çok önemli bir faktör olarak kabul edilse de, iş kalitesi belirlenirken pek çok faktörün aynı anda göz önünde bulundurulması gerekmektedir. İş kalitesini etkileyen pek çok unsurun olması; hangilerinin dikkate alınacağına ve nasıl değerlendirileceğine karar verilmesini de güçleştirmektedir. Bunlara ücret, çalışma süresi, sosyal güvenlik kapsamı, sözleşme türü, iş güvenliği derecesi, ücretli izin, ebeveyn izni ve 
hastalık iznine erişim ve kariyer ilerleme firsatları örnek verilebilir (ILOstat, 2021). Ancak, farklı çerçeveler ve temel göstergelerin çeşitliliği birbiriyle örtüşmesine ve birbirine benzerlik göstermesine rağmen, literatürde iş kalitesini ve işyerinde çalışan memnuniyetini değerlendirmeye yönelik hangi kriterlerin ve temel göstergelerin kullanılması gerektiği konusunda tam bir fikir birliği bulunmamaktadır (Kauhanen ve Nätti, 2015, s.785). Örneğin iş kalitesi hesaplanırken, farklı göstergelerden yararlanan Green (2006) çalı̧̧masında iş kalitesi göstergeleri olarak; becerileri (yaşam boyu öğrenme ve kariyer gelişimi dâhil), çalışma çabası, iş görevleri üzerinde özerklik/takdir yetkisi, ücretleri (ücretlerin adaletli olması dâhil) ve düşük riskler ve güvenliği (istihdam güvenliği ve fiziksel güvenlik) ele almıştır. Öte yandan Tilly (1996), iyi iş/kötü iş özelliklerini ücretler; beceri, eğitim ve sorumluluk; işgücü devri ve kariyer ilerlemesi ile incelemiştir.

Son zamanlarda mutluluk ekonomisi çerçevesinde iş kalitesi yaklaşımı, iş memnuniyeti ve çalışanların yaşam memnuniyetine yönelik geliştirilen anketlerde çalışanların bakış açılarının dikkate alınmasıyla zenginleştirilmiştir. Bu tür anketler, insanlara kendileri için neyin daha önemli olduğunu sorarak, iş kalitesinin boyutlarını belirlemeyi mümkün kılmaktadır. Söz konusu anketlerde karşılaştırma etkileri ve alışkanlık etkisi hâkimdir. Örneğin çalışanlar, diğer koşullar eşitken, iş arkadaşlarından veya meslektaşlarından daha az ücret aldıklarında mutsuz olurlar ve bu durumda ücret artışlarının yalnızca geçici bir etkisi vardır. Bu sonuçlar, insana yakışır yaşam standartları, ücret eşitliği ve iyi ücret hareketliliğinin iş kalitesi göstergeleri olarak kabul edilebileceğini göstermektedir (Erhel ve Guergoat-Larivière, 2010, s.1).

2008 Küresel Ekonomik Krizi sonrasında da pek çok ülkede bazı araştırmacılar, politika yapıcılar ve sosyal istatistikçiler tarafından iş kalitesine ilişkin endişeler yeniden dile getirilmeye başlanmış, akademik çevrelerin yanı sıra, uluslararası örgütlerin de iş kalitesine yönelik ilgisi artmıştır. Bu bağlamda uluslararası kuruluşlar da iş kalitesi ölçümüne ilişkin önemli çalışmalar yürütmüştür. Bu anlamda iş kalitesinin farklı yönlerini ölçmek ve ülkeler arası karşılaştırma yapabilecek göstergeler belirlemek için uluslararası düzeyde birkaç önemli girişimde bulunulmuştur. Örneğin, Uluslararası Çalışma Örgütü (ILO) İnsana Yakışır İş Gündeminin uygulanmasında kaydedilen ilerlemeyi izlemek için kullanılabilecek 50'den fazla İnsana Yakışır İş Göstergesine ilişkin bir kılavuz yayınlamıştır (OECD, 2014, s.86). Diğer taraftan iş kalitesini ölçmeye yönelik 
Eurofound (2002) iş ve istihdam kalitesinin değerlendirilmesinde kullanılmak üzere kariyer ve istihdam güvenliği, çalışanların sağlığı ve mutluluğu, beceri geliştirme ve iş-yaşam dengesinden oluşan dört ana boyutu olan analitik bir çerçeve önermiştir. Ayrıca Avrupa Birliği, "daha fazla ve daha iyi iş” hedefi doğrultusunda, 10 boyutlu Laeken göstergelerini kabul etmiştir (Kauhanen ve Nätti, 2015, s.786). Benzer şekilde, Birleşmiş Milletler Avrupa Ekonomik Komisyonu (UNECE) (2010), Eurostat ve ILO ile işbirliği içinde, iş kalitesinin çeşitli boyutlarını ölçmek için operasyonel kılavuzlar geliştirmiştir. Son olarak, OECD de, üç boyut ve dokuz göstergeden oluşan bir "IŞs Kalitesi Çerçevesi" yayınlamıştır (OECD, 2014, s.83). OECD (2016) iş kalitesinin ölçülmesine ve değerlendirilmesine yönelik, iş kalitesinin hem çalışanların refahı için önemli, hem de politikayla ilgili olan kazanç kalitesi, işgücü piyasası güvencesi ve çalışma ortamından oluşan üç objektif ve ölçülebilir boyutu dikkate almıştır. $\mathrm{Bu}$ çalışma kapsamında yaşam memnuniyeti ile iş kalitesi arasındaki ilişkinin incelenmesinde OECD’nin İş Kalitesi Çerçevesi kullanılmış ve kullanılan göstergelerin neyi ölçtügü çalışmanın bağımsız değişkenler başlığı altında ayrıntılı olarak incelenmiştir.

\section{Araştırmanın Yöntemi}

Bu bölümde çalışmada kullanılan bağımlı ve bağımsız değişkenlerin tanımlandığı araştırma verisi ve çalışmada kullanılacak analiz tekniğinin yanı sıra, basit ve çoklu regresyon analiz sonuçları incelenecektir.

\section{Araştırma Verisi}

Bu çalışma kapsamında kullanılan veriler, temel olarak OECD veri tabanından ve yayınlarından alınmıştır. OECD ülkelerinin 2014/2015 yılına ait yaşam memnuniyeti skorları OECD’nin (2016a) Sosyal Göstergeler çalışmasından, Tablo 1'de gösterilen “iş kalitesi göstergeleri” ise, OECD İş Kalitesi veri tabanından alınmıştır. Ancak OECD’nin iş kalitesi boyutlarına ilişkin en güncel veriler 2015 yılına ait olduğu için temel olarak 2015 yılı verileri kullanılmıştır. Ayrıca 2015 yılına ait verisi eksik olan ülkelerde geriye doğru en güncel yıl verisi kullanılmış (OECD, 2021a) olup, kullanılan veriler ve verilerin hangi yıla ait olduğu çalışma sonundaki EK TABLO'da detaylı bir biçimde gösterilmiştir. Kullanılan değişkenlerin betimleyici analiz sonuçları ise, Tablo 1 'de sunulmuştur. 
Tablo 1

Betimleyici Istatistikler

\begin{tabular}{|l|c|c|c|c|c|c|c|c|}
\hline & N & Min. & Maks. & Ort. & $\begin{array}{c}\text { Std. } \\
\text { Sapma }\end{array}$ & $\begin{array}{c}\text { Çarpıklık } \\
\text { (Skewness) }\end{array}$ & $\begin{array}{c}\text { Basıklık } \\
\text { (Kurtosis) }\end{array}$ & $\begin{array}{c}\text { K-S } \\
\text { Testi }\end{array}$ \\
\hline $\begin{array}{l}\text { Yaşam } \\
\text { memnuniyeti } \\
\text { skoru }\end{array}$ & 34 & 5,10 & 7,60 & 6,64 & 0,74 & $-0,62$ & $-0,77$ & $0,133^{*}$ \\
\hline İstihdam (\%) & 34 & 39,05 & 79,25 & 56,83 & 7,47 & 0,20 & 1,91 & $0,145^{*}$ \\
\hline $\begin{array}{l}\text { Kazanç kalitesi } \\
\text { \$ }\end{array}$ & 34 & 4,74 & 32,40 & 17,55 & 8,41 & 0,14 & $-1,13$ & 0,179 \\
\hline İşsizlik riski \% & 34 & 3,39 & 28,61 & 8,61 & 5,37 & 2,59 & 7,59 & 0,174 \\
\hline $\begin{array}{l}\text { Çalışma süreleri } \\
\text { inelastikliği \% }\end{array}$ & 32 & 19,42 & 55,65 & 35,25 & 8,65 & 0,29 & $-0,04$ & $0,068^{*}$ \\
\hline $\begin{array}{l}\text { İs otonomisi } \\
\text { ve öğrenme } \\
\text { frrsatları \% }\end{array}$ & 32 & 7,32 & 51,07 & 25,14 & 11,95 & 0,51 & $-0,26$ & $0,086^{*}$ \\
\hline $\begin{array}{l}\text { Kariyer ilerleme } \\
\text { firsat1 \% }\end{array}$ & 32 & 5,35 & 42,49 & 18,35 & 9,98 & 0,99 & 0,11 & 0,202 \\
\hline
\end{tabular}

Kaynak: OECD Stat, 2021a.

* İstatistiksel olarak anlamlılık düzeyi $p>0,05$.

Tablo 1'deki değişkenlerin standart sapma değerlerinin, belirli toleranslar dâhilinde, ortalama (mean) etrafinda yoğunlaştığı görülmektedir. Tablo 1'deki değişkenlere uygulanan Kolmogorov-Smirnov (K-S) testinde yaşam memnuniyeti, istihdam oranı, çalışma süreleri inelastikliği ve iş otonomisi ve öğrenme firsatları değişkenlerine ait veriler normal dağılım varsayımını karşılıyorken, kazanç kalitesi, işsizlik riski ve kariyer ilerleme firsatı değişkenlerine ait verilerin karşılamadığı görülmektedir. Ancak işsizlik riski dışındaki diğer değişkenlerin basit çarpıklık ve basıklık değerlerinin $\pm 2,00$ aralı̆̆ında (Lomax ve Hahs-Vaughn, 2012, s.89-90) olması, bu değişkenlerin de normal dağılım koşulunu sağladığını göstermektedir. Diğer taraftan, çarpıklık değerinin \pm 3 , basıklık değerinin ise, \pm 10 aralığında olmasını kabul edilebilir bir normallik aralığı olarak gören bazı araştırmacılar da bulunmaktadır (Kline, 2009, s.240). Bu açıdan, işsizlik riski değişkeninin de belirli toleranslar dâhilinde, normal dağılım koşuluna uygun olduğu kabul edilebilir. Ülkelerin negatif değere sahip yaşam memnuniyeti skoru sola çarpıklığı gösteriyorken, pozitif çarpıklık değerine sahip istihdam oranı, kazanç kalitesi, işsizlik riski, çalışma süreleri inelastikliği, iş otonomisi ve öğrenme fursatları ve kariyer ilerleme firsatı değişkenlerinin değerleri ise, sağa çarpıklığa işaret etmektedir.

\section{Bağımlı Değişken}

Yaşam memnuniyeti yalnızca insanların ekonomik gelişimini değil, aynı zamanda farklı deneyimlerini ve yaşam koşullarını da dikkate almaktadır. $\mathrm{Bu}$ 
açıdan yaşam memnuniyetini ölçmeye yönelik çeşitli ölçekler geliştirilmiştir. Ancak bunlar içinden ilk kez 1965 yılında Hadley Cantril tarafından kullanılan ve Gallup'un Dünya Anketinde kullanıldıktan sonra önemli ölçüde popüler hale gelen "Cantril'in Yaşam Memnuniyeti Merdiveni”dir. Cantril'in tekniği, katılımcılardan yaşamdan duydukları memnuniyeti " 0 " ve " 10 " değerleri arasında bir puanla derecelendirmelerini isteyen anket sorusu ile ölçülmektedir (Levin ve Currie, 2014, s.1049). OECD ülkelerinde yaşam memnuniyeti tipik olarak kullanılan soru formatı şöyledir: "bir bütün olarak düşündügünüzde son zamanlardaki hayatınızdan ne kadar memnunsunuz? 0 "hiç memnun değil" ile 10 "çok memnun" arasında değişen bir ölçekte derecelendiriniz" (OECD, 2021b). Tüm ülkelerde ulusal olarak 15 yaş ve üzeri nüfusu temsil eden bu ölçek, dünya çapında 150'den fazla ülkenin yaşam memnuniyeti puanlarının ortalamasını yansıtan "yaşam memnuniyeti skorunu” belirlemek için kullanılmaktadır (OECD, 2016a, s.126). Bu çalışmada OECD ülkelerini birbiri ile karşılaştırabilmek için OECD ülkelerinin 2014/2015 y1lına ait yaşam memnuniyeti skorları kullanılmıştır.

\section{Bağımsız Değişkenler}

Ístihdam oranı işgücüne katılımı ve istihdam yaratmayı teşvik etmek açısından, istihdam miktarının en temel göstergesidir. Ancak istihdam oranının işgücü piyasası performansına ilişkin tam bir bilgi sağlayıp sağlamadığı tartışmalıdır. Ancak yine de potansiyel işgücü arzı içerisinden istihdam başarıları açısından ülkeler karşılaştırılırken, ülkelerin istihdam oranları önemli bir göstergedir (OECD, 2017, s.25). Diğer taraftan iş kalitesini tanımlayan boyutlar, işgücü piyasası performansının yanı sıra, politikaların ve kurumların rolünü değerlendirirken, mevcut iş sayısı, yani istihdam miktarı ile birlikte eşzamanlı olarak dikkate alınmalıdır (OECD, 2014, s.85). Bu açıdan çalışmanın bireyin yaşam memnuniyetini artıran bir etkisinin olduğu kabul edilmektedir (Green, 2006, s.14).

Kazanç ya da ücret kalitesi, ülkeler arası bir iş kalitesi karşılaştırmasında, önemli bir odak noktasıdır. Kazanç seviyesi, bireylerin maddi yaşam standartlarına katkılarını değerlendirmek için önemli bir kıyas sağlarken, kazançların işgücüne dağıtılma şekli de refah için önemlidir. Bu nedenle hem kazanç düzeyini, hem de işgücüne dağılımını açıklayan bir endeksle kazanç kalitesi ölçülmektedir (OECD, 2016b, s.1). Bireysel düzeyde, kazançlar brüt 
veya net olarak ve saatlik, aylık ve hatta yıllık olarak ölçülebilir. OECD iş kalitesi çerçevesinde, ABD doları (\$) cinsinden brüt saatlik ücretleri tüm çalışanlar arasındaki kazançların aritmetik ortalaması ile ölçülmektedir (Cazes, Hijzen ve Saint-Martin, 2016, s.22). Bu açıdan kazanç kalitesi, düşük ücretli çalışanların durumuna özel bir vurgu yaparak, istihdamın çalışanların ve ailelerinin maddi yaşam standartlarına ne ölçüde katkıda bulunduğunu ölçmektedir (OECD, 2014, s.84). Yani kazanç kalitesi, çalışanların işlerinden elde ettikleri kazançların, hem ortalama seviyeyi, hem de kazançların işgücüne dağıtılma şeklini hesaba katarak çalışanların yaşam memnuniyetine ne ölçüde katkıda bulunduğunu göstermektedir (OECD, 2017, s.27). Bu boyutun varsayımına göre, işten elde edilen kazanç ve diğer maddi faydalar ne kadar yüksekse, iş kalitesinin de o kadar yüksek olduğu kabul edilmektedir (Bowlby vd., 2010, s.6; Yazıcıŏlu ve Kubilay, 2017).

Işsizlik riski, çalışanların karşılaşabileceği en önemli sosyal tehlikedir (Cazes vd., 2016, s.22). Bu açıdan işsizlik riski, ekonomik güvencenin kaybolma olasılığ 1 ve iş kaybının çalışanlar için ekonomik maliyeti ile ilişkili yönlerini ele almaktadır (OECD, 2016b, s.1). Aslında işsizlik riski, işsizliğe bağlı kazanç kaybıyla ilişkilidir. Bu kazanç kaybı, işsizlik riskine ve işsizlik durumunda devlet transferleri, işsizlik yardımları ve sosyal yardımlar ile sağlanan kazanç kaybını hafifletme derecesine bağlıdır (Cazes vd., 2016, s.23). İşsizlik riski, hem işsiz kalma olasılığını, hem de işsizlik süresinin ortalama beklenen süresini kapsamakta ve "işsizlerin aylık işe girme olasılı̆̆ ile beklenen ortalama işsizlik süresinin (ay olarak) çarpımı olarak ölçülmektedir. Bir aydan daha kısa süredir işsiz olanların, bir ay önceki istihdam edilenlerin saylsına oranıdır. Beklenen işsizlik süresi ise, bir ay ve daha uzun süredir işsiz olanların, bir ay önceki işsizlerin sayısına oranıdır" (OECD, 2021a).

İşsizlik riski de yaşam memnuniyetinin önemli bir belirleyicisi olmakla birlikte, işsizlik sigortası gibi, pasif istihdam politikaları bireylerin işsiz kaldıktan sonra iş bulamama endişelerini azaltarak, işsizlik riskinin çalışanların yaşam memnuniyeti üzerindeki negatif etkisini düşürmektedir (OECD, 2014, s.80). İşsizlik riskinin güvece altına alınmadığı durumlarda, çalışanın başka bir gelir kaynağı da yoksa emeğinden başka bir geçim kaynağı olmayan çalışanlar açısından işsizlik mutlak bir kazanç kaybı anlamına gelmektedir. $\mathrm{Bu}$ kazanç kaybı da çalışanların yaşam memnuniyetlerini önemli ölçüde düşürmektedir. Dolaysıyla bireysel gelirlerde ve işgücü piyasası beklentilerinde 
bozulma yaşayan ülkelerin yaşam memnuniyeti skorlarının daha düşük olması beklenmektedir (OECD, 2016a, s.126).

Çalışma ortamı kalitesi, sadece kaliteli bir işe sahip olmak ya da iyi ücret kazanmak anlamına gelmez, aynı zamanda kişisel başarıya elverişli bir çalışma ortamında çalışmak anlamına da gelmektedir (OECD, 2014, s.103). Çalışma ortamı kalitesi, yapılan işin doğası ve içeriği, çalışma süresi düzenlemeleri, iş özerkliği ve öğrenme firsatları ve kariyer fırsatları ile ilgili faktörleri içermektedir (OECD, 2016b, s.1). Çalışma süresi kalitesi kendine, arkadaşlara ve aileye daha sınırlı zaman ayırma açısından, işten kişisel hayata olumsuz yayılma potansiyeli nedeniyle iş-yaşam dengesi ile uyumlu çalışma sürelerini ayarlama esnekliğinin yanı sıra, fazla çalışmanın derecesi ve iş temposunu içermektedir (Warren ve Lyonette, 2020, s.386). Bütün bu unsurlar çalışanlar üzerindeki iş stresini artırmaktadır. Bu açıdan OECD iş kalitesi çerçevesinde işle ilgili stres faktörlerinden biri de, yüksek iş yoğunluğunu ve esnek çalışmayı da içeren çalışma süreleri esnekliğidir (OECD, 2017, s.27). Çalışma süreleri esnekliği, bir işin çalışanlara esnek çalışma imkânı sağlama derecesini ifade etmektedir (OECD, 2021a). Bu anlamda çalışma süreleri ve çalışma sürelerinin programlanması, iş kalitesinin önemli bir boyutunu oluşturmaktadır. Bu açıdan, uzun süreler boyunca veya anti-sosyal saatlerde çalışmak, çalışan için çok zorlayıcı ya da bir stres kaynağı olabilmektedir. Diğer taraftan, aşırı uzun veya gönülsüz kısa süreli çalışmanın hem insanların yaşam memnuniyeti, hem de iş-yaşam dengesiyle güçlü bir ilişkisi bulunmaktadır (Bowlby vd., 2010, s.6).

Çalışma ortamının kalitesi, yapılan işin doğası ve yoğunluğu, işin organizasyonu ve çalışma atmosferiyle yakıdan ilişkilidir. Bu açıdan çalışma ortamının kalitesi, bireysel yaşam memnuniyetinin önemli faktörlerinden birdir ve büyük ölçüde çalışanların işlerinde özerkliğe sahip olup olmadıklarına, öğrenme firsatlarına ve ayrıca iyi tanımlanmış iş hedeflerine ve kariyer firsatlarına sahip olup olmadıklarına bağlıdır (OECD, 2014, s.80). Çalışanların iş görevlerini yerine getirmek için gereken iş görevlerini ve yöntemlerini seçme ve değiştirme özgürlüğünü ve işteki formel ve enformel öğrenme (eğitim) firsatlarını dikkate alan iş otonomisi ve öğrenme firsatlarıdır (Cazes vd., 2016, s.24). İş otonomisi, "çalışanların görev sırası ve çalışma yöntemleri gibi acil is faaliyetlerini yerine getirme biçimlerini etkileme kabiliyetini ifade etmektedir. Ögrenme firsatlart ise, hem işi yaparak işyerinde enformel ögrenmeyi, hem de işveren tarafindan veya çalışma saatleri içerisinde sağlanan formel ĕ̆itim 
fırsatlarını içermektedir" (OECD, 2021a). Çalışanların işleriyle ilgili otonomilerinin artması, özel olarak iş memnuniyetlerini artırarak, genel olarak yaşam memnuniyetini de olumlu yönde etkilemesi beklenmektedir.

Çalışma ortamının kalitesi açısından, işlerin kariyer ilerleme fırsatı sunup sunmadığ da oldukça önemlidir (OECD, 2017, s.27). Bu bağlamda kariyer ilerleme firsatı oranı çalışanların "işlerinde ilerleme bekleyen çalışanların yüzdesini ifade etmektedir" (OECD, 2021a). Bu açıdan yüksek kariyer ilerleme fırsatının çalışanların yaşam memnuniyetini de artırması beklenmektedir.

\section{Analiz Tekniği}

Regresyon analizi, bağımlı değişken ile bir bağımsız değişken ya da birden fazla değişken arasındaki ilişkinin açıklanmasında oldukça sık kullanılan bir tekniktir. Bu çalışma kapsamında da bağımlı değişken ile bağımsız değişkenler arasındaki ilişkinin açıklanmasında, hem basit, hem de çoklu doğrusal regresyon modelleri kullanılacaktır. Basit doğrusal regresyon modeli $\mathrm{Y}_{i}=\beta_{0}+\beta_{1} \mathrm{X}_{1}+e_{i}$ denklemiyle formüle edilmektedir. Bu denklemde $Y_{i}$ bağımlı değişkenin alacağı değer, $\beta_{0}$ sabit değer, $\beta_{1}$ bağımsız değişkenin katsayısı ve $e_{i}$ ise, hata terimini ifade etmektedir. Ancak bağımlı değişkeni tahmin etmede kullanılan bağımsız değişken sayısı birden fazla ise, bu durumda çoklu doğrusal regresyon analizi kullanılmaktadır. Esas olarak çoklu doğrusal regresyon modeli, basit doğrusal regresyon modelinin birden fazla açıklayıcı değişken $\left(\mathrm{X}_{1}, \mathrm{X}_{2}, \ldots ., \mathrm{X}_{\mathrm{p}}\right)$ içerecek şekilde genişletilmiş halidir. Yani çoklu doğrusal regresyon denklemi basit doğrusal regresyonun aynısıdır, ancak daha fazla terime sahiptir (Tranmer vd., 2020, s.11). Bu açıdan çoklu doğrusal regresyon denklemi şu şekilde formüle edilmektedir:

$$
\mathrm{Y}_{i}=\beta_{0}+\beta_{1} \mathrm{X}_{1 i}+\beta_{2} \mathrm{X}_{2 i}+\cdots+\beta_{p} \mathrm{X}_{p i}+e_{i}
$$

Çoklu doğrusal regresyon modelinde $\mathrm{H}_{0}$ hipotezi tüm regresyon katsayılarının sıfira eşit olduğu $\left(\mathrm{H}_{0}: \beta_{1=} \beta_{2=\ldots . . .} \beta_{\mathrm{p}}=0\right)$ şeklinde kurulurken, $\mathrm{H}_{1}$ hipotezi ise, en az $\beta_{1}$ 'nin sıfırdan farklı olduğu şeklinde kurulmaktadır. Parametrelerin tek tek istatistiksel olarak anlamlılığ için $t$ testi ve modelin bir bütün olarak anlamlı olup olmadığının test etmek için ise, $F$ testi yapılmaktadır (Küçüksille, 2014, s.259). 


\section{Basit Doğrusal Regresyon Analizi}

$\mathrm{Bu}$ bölümde yaşam memnuniyeti ile iş kalitesi göstergeleri arasındaki ilişki ayrı ayrı basit doğrusal regresyon modelleriyle ele alınmıştır. Aşağıdaki grafiklerde OECD ülkelerinin yaşam memnuniyeti skoru ortalaması $(6,64)$ ve standardize edilmiş iş kalitesi göstergeleri açısından bölgelere ayrılmış ve iş kalitesi göstergelerinin ayrı ayrı yaşam memnuniyetini açıklayıcısı olup olmadığ 1 analiz edilmiştir.

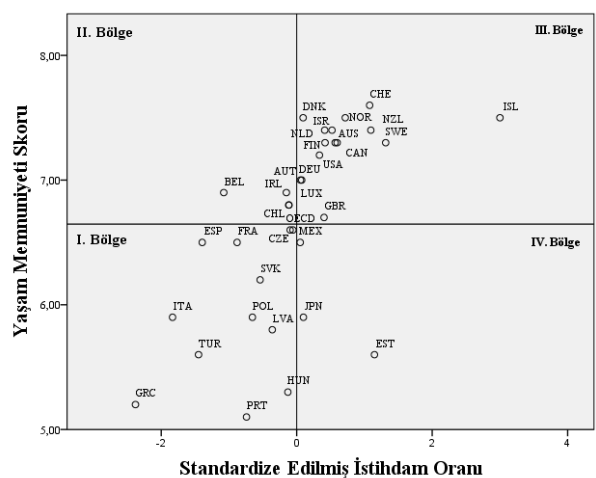

Grafik 1. Yaşam memnuniyeti skoru (YMS) ile istihdam oranı (İO) ilişkisi $\mathrm{YMS}=3,109+0,062 \mathrm{I} \mathrm{O} ; p<0,001 ;\left(\mathrm{R}^{2}=0,388\right)$.

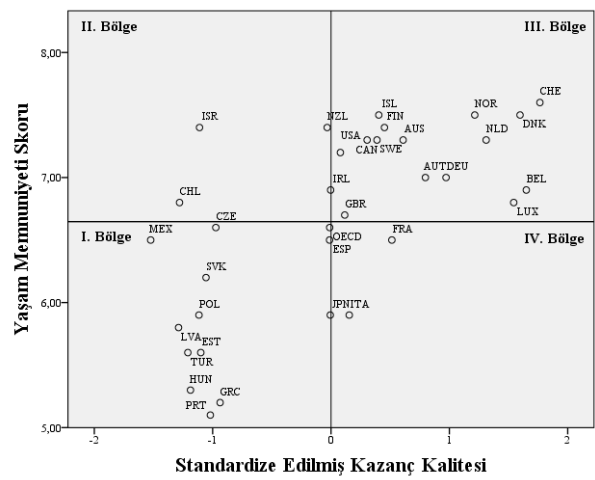

Grafik 2. Yaşam memnuniyeti skoru (YMS) ile kazanç kalitesi (KK) ilişkisi $\mathrm{YMS}=5,624+0,058 \mathrm{KK} ; p<0,001 ;\left(\mathrm{R}^{2}=0,431\right)$.

Kaynak: OECD Stat, 2021a.

Grafik 1'deki doğrusal regresyon modelinde istihdam oranları yüksek olan ülkelerin yaşam memnuniyeti skorlarının da yüksek olduğu görülmektedir. Genel olarak, istihdam oranı açısından iyi performans gösteren III. Bölgede yer alan ülkeler daha iyi yaşam memnuniyeti skoruna sahipken, I. Bölgede yer alan ülkeler için bunun tersi geçerlidir. Yani, III. Bölgede yer alan ülkeler istihdam oranı ve yaşam memnuniyeti açısından diğer ülkelerden pozitif ayrışırken, daha çok eski doğu bloğu Avrupa ülkeleri ve Türkiye'den oluşan I. Bölgede yer alan ülkelerin negatif ayrıştığı görülmektedir. Diğer taraftan, regresyon denkleminden istihdam oranının yaşam memnuniyetini anlamlı bir şekilde açıkladığı görülmektedir.

Grafik 2'de gösterilen modelde, çalışanların kazanç kalitesindeki artışın ülkelerin yaşam memnuniyeti skorlarını olumlu yönde etkilediği izlenmektedir. $\mathrm{Bu}$ sonuç, işten elde edilen aylık kazancın yükselmesi yaşam memnuniyetini olumlu yönde etkilediğini gösteren Yazıcıoğlu ve Kubilay'ın (2017) bulgularını 
da desteklemektedir. Bu anlamda kazanç kalitesinin görece yüksek olduğu III. Bölgede yer alan ülkelerin yaşam memnuniyeti skorları diğer ülkelerden daha yüksek iken, kazanç kalitesinin nispeten düşük olduğu I. Bölgede yer alan ülkelerin yaşam memnuniyeti skorları diğer ülkelerden daha düşüktür. Ayrıca, regresyon denklemine göre, kazanç kalitesi yaşam memnuniyetini anlamlı bir şekilde açıklamaktadır.

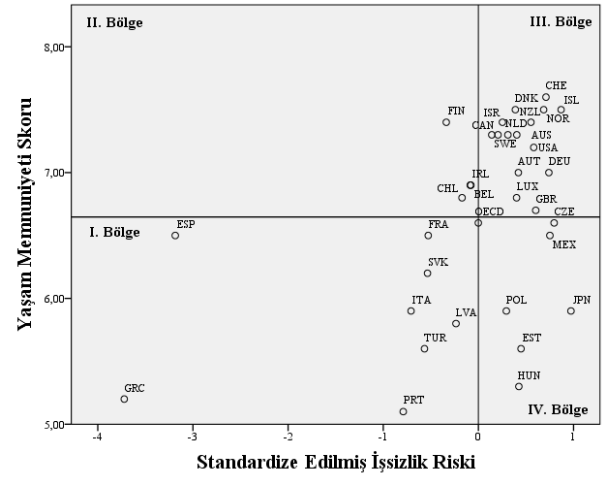

Grafik 3. Yaşam memnuniyeti skoru (YMS) ile işsizlik riski (IR) ilişkisi

YMS= 7,168 - 0,060İ; $p<0,01 ;\left(\mathrm{R}^{2}=0,189\right)$.

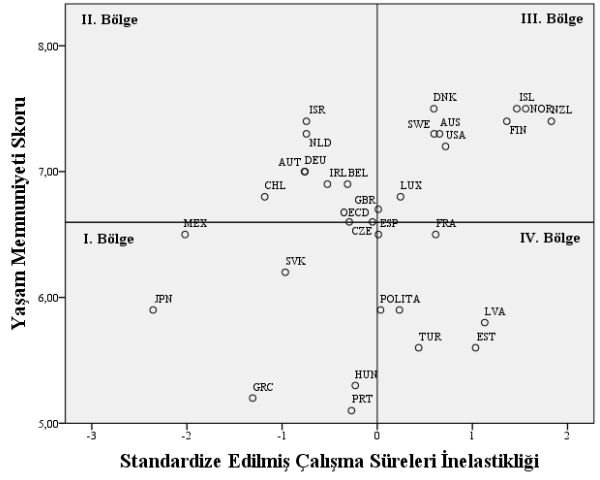

Grafik 4. Yaşam memnuniyeti skoru (YMS) ile çalışma süreleri inelastikliği (ÇSI) ilişkisi $\mathrm{YMS}=7,589-0,027 C ̧ S \dot{;} ; p>0,05 ;\left(\mathrm{R}^{2}=0,096\right)$.

Kaynak: OECD Stat, 2021a.

Grafik 3 'teki regresyon modelinde, işsizlik riskindeki artışın ülkelerin yaşam memnuniyeti skorlarını düşürdüğü gözlenmektedir. Buna göre, regresyon denklemi işsizlik riskinin yaşam memnuniyetini anlamlı bir şekilde açıkladığını göstermektedir. Çalışanların işsizlik riskinin yüksek olduğu I. Bölgede yer alan ülkeler, yaşam memnuniyet skorları açısından da diğer ülkelerden negatif ayrışıyorken, III. Bölgede yer alan ülkelerin pozitif ayrıştığı izlenmektedir. Bu sonuçlar, işsizlik riskindeki artışın, çalışanların yaşam memnuniyetlerinde istatistiksel olarak anlamlı bir azalmaya yol açtığı sonucuna ulaşan OECD araştırmasını (2014) da teyit etmektedir. OECD araştırmasına göre, işsizlik riskindeki artışın çalışanların yaşam memnuniyetleri üzerindeki etkisi, hanehalkı gelirindeki \%2'den fazla bir azalmanın etkisine eşdeğerdir. Bu sonuç, i) işsizliğin maliyetinin, bu maliyete karşılık gelen gelir kaybından önemli ölçüde daha fazla olduğunu, ii) çalışanların riskten kaçındığını veya iii) işsizlik riskinin yaşam memnuniyetini etkileyen diğer faktörlerle ilişkili olduğunu yansıtmaktadır (OECD, 2014, s.101). Örneğin ABD, Almanya ve diğer bazı Avrupa ülkelerine ait verileri kullanan Lüchinger, Meier ve Stutzer, (2010), özel sektör 
çalışanlarının yaşam memnuniyetlerinin, işsizlik oranlarındaki dalgalanmalara, kamu sektörü çalışanlarından çok daha duyarlı olduğu sonucuna ulaşmışlardır.

Grafik 4'teki modelde, çalışma süreleri inelastikliği ile yaşam memnuniyeti arasında ters yönlü zayıf bir korelasyon bulunmakla birlikte, çalışma süreleri inelastikliğindeki artışın ülkelerin yaşam memnuniyeti skorlarını olumsuz etkilediği görülmektedir. Buna göre, yaşam memnuniyeti açısından negatif ayrışan IV. Bölgede yer alan ülkelerde çalışma sürelerinin daha elastik olması; pozitif ayrışan II. Bölgede yer alan ülkelerde ise, çalışma sürelerin daha inelastik olması, iki değişken arasındaki korelasyonu zayıflatmaktadır. Diğer taraftan, çalışma sürelerinin görece daha elastik olduğu III. Bölgede yer alan ülkelerde çalışanların yaşam memnuniyetinin daha yüksek olduğu gözleniyorken, çalışma sürelerinin daha inelastik olduğu I. Bölgede yer alan ülkelerde ise, çalışanların yaşam memnuniyetinin nispeten daha düşük olduğu izlenmektedir. Ancak, regresyon denklemine göre, çalışma süreleri inelastikliği yaşam memnuniyetini anlamlı bir şekilde açıklayamamaktadır.
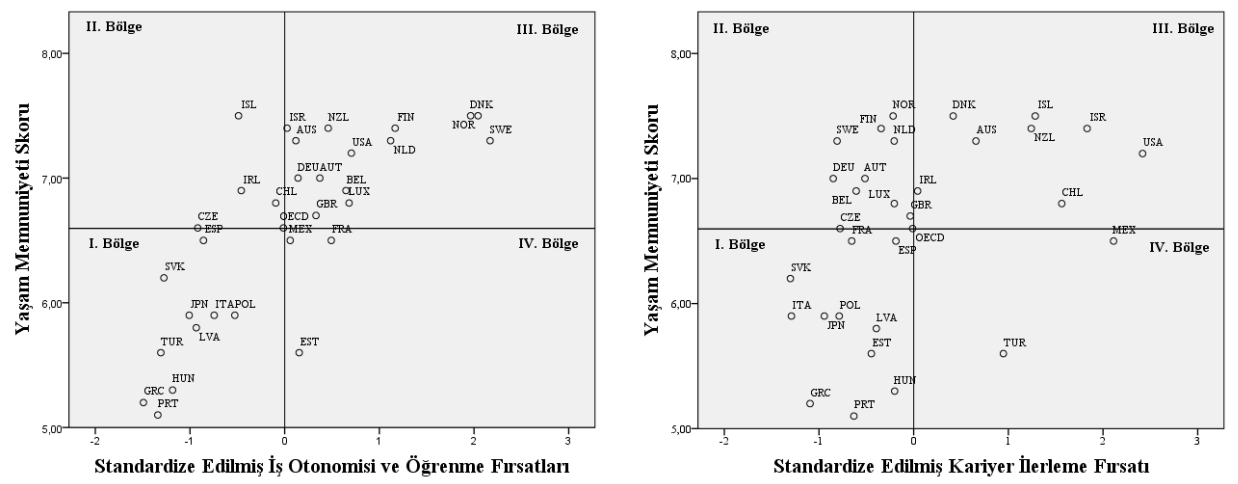

Grafik 5. Yaşam memnuniyeti skoru (YMS) ile Grafik 6. Yaşam memnuniyeti skoru (YMS) ile iş otonomisi ve öğrenme firsatları (İOÖF) ilişkisi kariyer ilerleme fırsatı (KIF) ilişkisi $\mathrm{YMS}=5,457+0,047 \mathrm{IOÖF} ; p<0,001 ;\left(\mathrm{R}^{2}=0,574\right)$. YMS=6,088 + 0,030KİF; $p<0,05 ;\left(\mathrm{R}^{2}=0,166\right)$. Kaynak: OECD Stat, 2021a.

Grafik 5 'teki modelde, iş otonomisi ve öğrenme fırsatlarındaki artışın, ülkelerin yaşam memnuniyeti skorlarını lineer bir modda yükselttiği görülmektedir. Genel olarak, iş otonomisi ve öğrenme firsatları yüksek olan III. Bölgede yer alan ülkeler, yaşam memnuniyeti açısından pozitif ayrışırken, düşük olan I. Bölgede yer alan ülkelerin negatif ayrıştığı gözlenmektedir. Ayrıca, regresyon denkleminden iş otonomisi ve öğrenme fursatlarının yaşam memnuniyetini anlamlı bir şekilde açıkladığı görülmektedir. 
Son olarak, Grafik 6' daki modelde, çalışanların kariyer ilerleme firsatlarındaki artışın ülkelerin yaşam memnuniyeti skorlarını yükseltici bir etkisinin olduğu izlenmektedir. Ayrıca, kariyer ilerleme firsatının yaşam memnuniyetinin bir açıklayıcısı olduğu gözlenmektedir. Kariyer ilerleme firsatları ile yaşam memnuniyeti ilişkisinde I. Bölgede yer alan ülkeler negatif ayrışmasına karşın, III. Bölgede yer alan ülkelerin pozitif ayrıştığı açıkça görülmektedir.

\section{Çoklu Doğrusal Regresyon Analizi}

\section{Araştırma Modeli ve Hipotezleri}

Çalışmaya ilişkin araştırma modelinin bağımsız değişkeni OECD ülkelerinin "yaşam memnuniyeti skoru", bağımlı değişkenleri ise "istihdam oranı, kazanç kalitesi, işsizlik riski, çalışma süreleri inelastikliği, iş otonomisi ve öğrenme firsatlart ve kariyer ilerleme firsatı"dır. Oluşturulan araştırma modelinin hipotezleri ise, şu şekilde geliştirilmiştir:

" $H_{0}=$ bağımsız değişkenlerden hiç biri yaşam memnuniyetini anlamlı olarak açılayamamaktadır."

" $H_{1}=$ bă̆ımsız değişkenlerden en az biri yaşam memnuniyetini anlamlı olarak açıklamaktadır."

Ayrıca $\mathrm{H}_{1}$ hipotezinin kabul edilmesi durumunda, analiz kapsamında $t$ testi sonuçlarına göre bu bağımsız değişkenlerden hangilerinin OECD ülkelerinin yaşam memnuniyeti skorunun anlamlı birer açıklayıcısı olduğu sorusuna da cevap aranacaktır.

\section{Korelasyon Matrisi}

Hipotez testine geçmeden önce bir korelasyon matrisi oluşturularak, bağımsız değişkenler arasında yüksek düzeyde korelasyon olup olmadığının değerlendirilmesi gerekir. Korelasyon analizi incelenen iki metrik değişken arasındaki ilişkinin belirlenmesinde kullanılan istatistiksel bir analizdir. $\mathrm{Bu}$ anlamda korelasyon analizinde $\mathrm{X}$ ve $\mathrm{Y}$ gibi iki değişken arasında anlamlı bir ilişki olup olmadığı, var ise, ilişkinin gücü ve yönü analiz edilirken, iki değişkenden hangisinin neden, hangisinin sonuç olduğunu söylemek mümkün değildir. Korelasyon analizi sonucunda bir korelasyon katsayısı hesaplanmakta ve bu katsayı \pm 1 arasında bir değer almaktadır. Bu anlamda katsayı değerinin 
işareti negatif ise, iki değişken arasında ters yönlü, pozitif ise, doğru yönlü bir ilişki olduğu şeklinde yorumlanmaktadır (İslamoğlu ve Alnıçık, 2014, s.347-348).

Korelasyon matrisinde korelasyon katsayılarına bakılarak, modelde çoklu bağıntı sorunu olup olmadığına ilişkin bir ön kontrol de sağlamaktadır. Bu anlamda açıklayıcı değişkenler arasında çok yüksek bir korelasyonun $(r>0,9)$ olması, modelde çoklu bağıntı sorunu olduğuna işaret edebilmektedir (İslamoğlu ve Alnıaçık, 2014: 370).

Tablo 2

Korelasyon Matrisi

\begin{tabular}{|l|l|c|c|c|c|c|c|c|}
\hline \multicolumn{2}{|l|}{} & $\mathbf{1}$ & $\mathbf{2}$ & $\mathbf{3}$ & $\mathbf{4}$ & $\mathbf{5}$ & $\mathbf{6}$ & $\mathbf{7}$ \\
\hline $\mathbf{1}$ & $\begin{array}{l}\text { Yaşam memnuniyeti } \\
\text { skoru }\end{array}$ & 1 & & & & & & \\
\hline $\mathbf{2}$ & İstihdam (\%) & $0,649 * * *$ & 1 & & & & & \\
\hline $\mathbf{3}$ & Kazanç kalitesi \$ & $0,651^{* * *}$ & $0,478^{* *}$ & 1 & & & & \\
\hline $\mathbf{4}$ & İşsizlik riski (\%) & $-0,425^{* *}$ & $-0,683^{* * *}$ & $-0,227$ & 1 & & & \\
\hline $\mathbf{5}$ & $\begin{array}{l}\text { Çalışma süreleri } \\
\text { inelastikliği \% }\end{array}$ & $-0,350^{*}$ & $-0,340^{*}$ & $-0,264$ & 0,116 & 1 & & \\
\hline $\mathbf{6}$ & $\begin{array}{l}\text { İş otonomisi ve öğrenme } \\
\text { firsatları \% }\end{array}$ & $0,755^{* * *}$ & $0,524 * * *$ & $0,677 * * *$ & $-0,391 *$ & $-0,392 *$ & 1 & \\
\hline $\mathbf{7}$ & Kariyer ilerleme firsatı \% & $0,411^{* *}$ & 0,121 & $-0,152$ & $-0,281$ & $-0,119$ & 0,171 & 1 \\
\hline
\end{tabular}

Kaynak: OECD Stat, 2021a.

İstatistiksel anlamlllık düzeyi * $p<0,05 ; * * p<0,01 ; * * * p<0,001$.

Tablo 2'de gösterilen modelin korelasyon matrisinde bağımsız değişkenler arası ilişkide en yüksek korelasyonun istihdam oranı ile işsizlik riski arasında oluştuğu gözlenmektedir. Buna göre, istihdam oranı ile işsizlik riski arasında ters yönlü orta düzey $(\mathrm{r}=-0,683 ; p<0,001)$ anlamlı bir korelasyon bulunmaktadır. $\mathrm{Bu}$ anlamda, bağımsız değişkenler arasında çok yüksek bir korelasyon bulunmadığı için modelde şimdilik çoklu doğrusal bağlantı sorununun olmadığını söyleyebiliriz. Ancak bunun daha güçlü testlerle teyit edilmesi gerekmektedir. Diğer taraftan bağımlı değişken ile bağımsız değişkenler arasında en yüksek korelasyonun yaşam memnuniyeti ile iş otonomisi ve öğrenme firsatları arasında gerçekleştiği gözlenmektedir. Buna göre, yaşam memnuniyeti ile iş otonomisi ve öğrenme firsatları arasında doğru yönlü yüksek düzey $(\mathrm{r}=0,755 ; p<0,001)$ anlamlı bir korelasyon bulunmaktadır. 


\section{Hipotez Testi}

Araştırma kapsamında belirlenen hipotezlere yönelik belirlenen bağımsız değişkenleri kullanarak, OECD ülkelerinin yaşam memnuniyeti skorlarını açıklamak için çoklu doğrusal regresyon analizi gerçekleştirilmiştir. Geriye doğru seçim (Backward) yöntemi kullanılarak oluşturulan çoklu doğrusal regresyon modellerinin analiz sonuçları Tablo 3'te gösterilmektedir. Geriye doğru seçim yönteminde ilk olarak, tüm değişkenler modele dâhil edilir. Daha sonra bağımsız değişkenlerin tümünün tek tek anlamlı olduğu modele ulaşana kadar, en düşük $F$ değerine sahip bağımsız değişken modelden çıkarılarak yeni modeller oluşturulur.

Tablo3

Çoklu Doğrusal Regresyon Modelleri

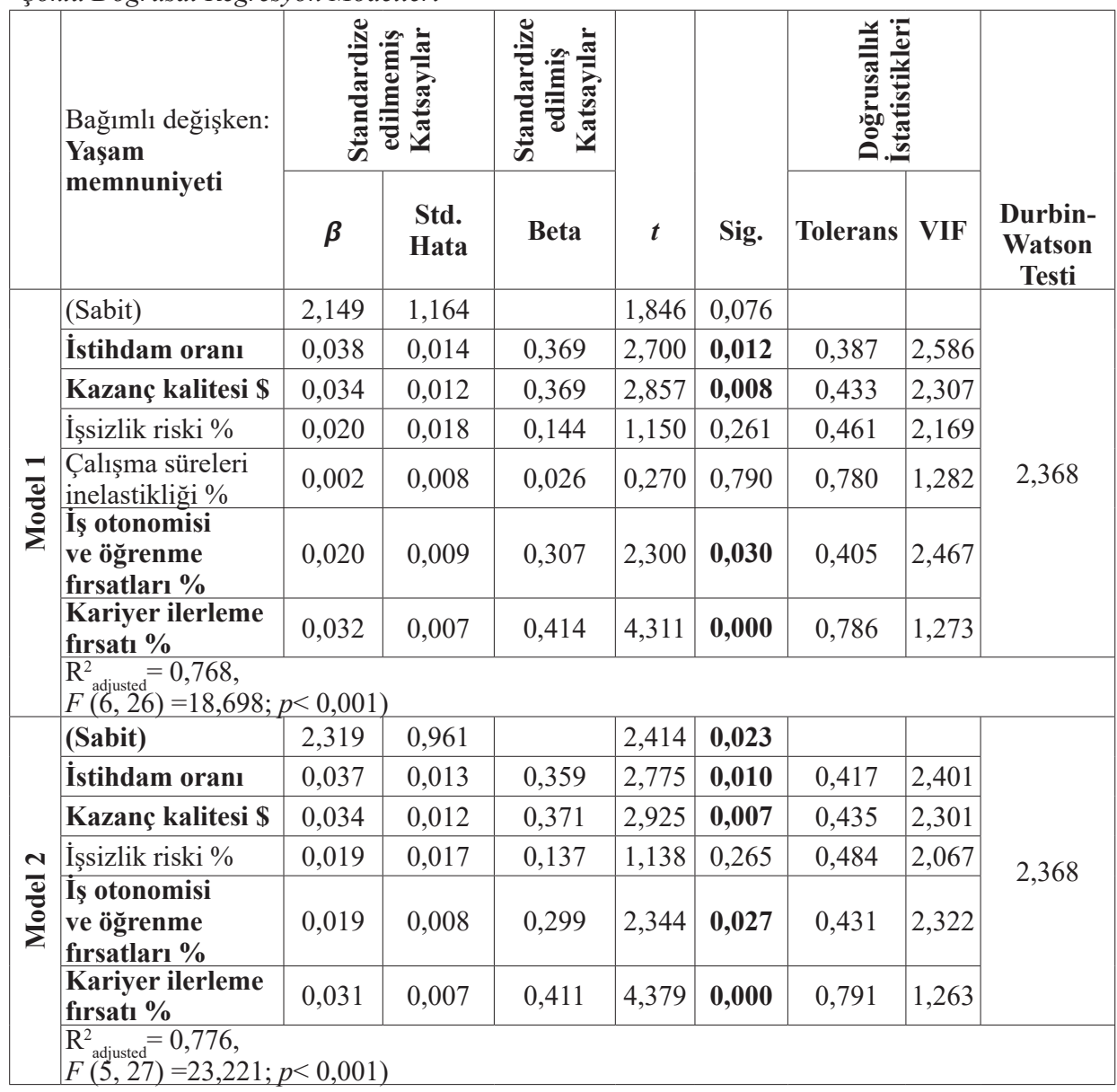




\begin{tabular}{|c|c|c|c|c|c|c|c|c|c|}
\hline \multirow{5}{*}{$\begin{array}{l}\frac{m}{0} \\
\frac{0}{2} \\
\sum\end{array}$} & (Sabit) & 3,152 & 0,626 & & 5,035 & 0,000 & & & \multirow{5}{*}{2,368} \\
\hline & İstihdam oranı & 0,027 & 0,010 & 0,267 & 2,634 & 0,014 & 0,688 & 1,454 & \\
\hline & Kazanç kalitesi \$ & 0,035 & 0,011 & 0,391 & 3,096 & $\mathbf{0 , 0 0 4}$ & 0,443 & 2,257 & \\
\hline & $\begin{array}{l}\text { İş otonomisi } \\
\text { ve öğrenme } \\
\text { fursatlar \% }\end{array}$ & 0,018 & 0,008 & 0,284 & 2,227 & $\mathbf{0 , 0 3 4}$ & 0,435 & 2,298 & \\
\hline & $\begin{array}{l}\text { Kariyer ilerleme } \\
\text { fursatı \% }\end{array}$ & 0,030 & 0,007 & 0,390 & 4,214 & $\mathbf{0 , 0 0 0}$ & 0,825 & 1,212 & \\
\hline
\end{tabular}

Kaynak: OECD Stat, 2021a.

Analiz sonucunda, kurulan her üç regresyon modelinin de anlamlı olduğu (Model 1 için $F(6,26)=18,698 ; p<0,001$; Model 2 için $F(5,27)=23,221 ; p<$ $0,001$; Model 3 için $F(4,28)=28,403 ; p<0,001)$ görülmüştür. Ayrıca DurbinWatson $(2,368)$ değerinden modellerin hata terimleri arasında bir otokorelasyon sorununun bulunmadığı anlaşılmaktadır. Bununla birlikte, tolerans değerleri ve VIF değerleri ( $\mathrm{VIF}<3$ ), modelde yer alan bağımsız değişkenler arasında çoklu bağıntı sorununun olmadığını göstermektedir. Bu sonuçlar, korelasyon matrisi sonuçlarını da teyit etmektedir.

Elde edilen bu sonuçlara göre, üç modelde de bağımsız değişkenlerden en az birinin OECD ülkelerinin yaşam memnuniyeti skorlarını anlamlı şekilde açıkladığı görülmektedir. Ancak en düşük $F$ değerine sahip "çalışma süreleri inelastikliği" Model 1'den çıkarılarak Model 2, daha sonra en düşük $F$ değerine sahip “işsizlik riski” Model 2'den atılarak Model 3 oluşturulmuştur. Böylece bağımsız değişkenlerin her birinin $t$ testlerinin istatistiksel olarak anlamlı olduğu Model 3'e ulaşılmıştır. Bu anlamda Model 3'teki bağımsız değişkenlerin bağımlı değişkendeki varyansın \%77,4'ünü $\left(\mathrm{R}^{2}{ }_{\text {adjusted }}=0,774\right)$ açıkladığı gözlenmektedir. Buna göre, OECD ülkelerinin yaşam memnuniyeti skorlarının \%22,6'sının araştırmaya dâhil edilmeyen başka değişkenlerce açıklandığını söylenebiliriz. Model 3'te, iş kalitesi göstergelerinden istihdam oranı $(\beta=0,267$; $t(28)=2,634 ; p<0,05)$, kazanç kalitesi $(\beta=0,391 ; t(28)=3,096 ; p<0,01)$, iş otonomisi ve öğrenme firsatları $(\beta=0,284 ; t(28)=2,227 ; p<0,05)$ ve kariyer ilerleme firsatının $(\beta=0,39 ; t(28)=4,214 ; p<0,001)$ OECD ülkelerinin yaşam memnuniyeti skorlarını pozitif yönlü ve anlamlı olarak açıkladığı anlaşılmaktadır. Bu sonuç, " $H_{1}=$ bağımsız değişkenlerden en az biri yaşam memnuniyetini anlamlı olarak açılklamaktadır" hipotezinin kabul edildiği anlamına gelmektedir. 


\section{Sonuç}

Bu çalışmada, OECD ülkelerinin yaşam memnuniyeti skorları ile iş kalitesi göstergeleri arasındaki ilişki, basit ve çoklu doğrusal regresyon analizi tekniği ile incelenmeye çalışılmıştır. Yaşam memnuniyetini etkileyen pek çok objektif ve sübjektif faktörün yanı sıra, iş kalitesinin de yaşam memnuiyetinin önemli bir belirleyicisi olduğu literatür incelemesinden anlaşılmaktadır.

Bu çalışmadan elde edilen analiz sonuçları, genel olarak, yaşam memnuniyeti ile altı boyutta incelenen iş kalitesinin her bir göstergesi arasındaki ilişkinin OECD ülkeleri arasında büyük ölçüde değiştiğini göstermektedir. Ayrıca elde edilen bulgulara göre, genel olarak, daha yüksek yaşam memnuniyeti skoruna sahip OECD ülkelerinde iş kalitesinin, daha düşük yaşam memnuniyeti skorlarına sahip OECD ülkelerinden daha iyi olduğu gözlenmektedir. Bu anlamda OECD (2014) de toplumsal refahın iş kalitesi açısından oldukça önemli olduğunun altını çizmektedir. Genel olarak bakıldığında, toplumsal refahın görece yüksek olduğu İsviçre, İzlanda, Danimarka, İsveç, Norveç, Finlandiya, Hollanda ve Yeni Zelanda, yaşam memnuniyeti skoru ve iş kalitesi göstergeleri ilişkisi açısından diğer ülkelere göre, nispeten daha iyi bir performansa sahipken, toplumsal refahın görece düşük olduğu Yunanistan, Portekiz, Macaristan ve Türkiye'nin daha kötü bir performans sergilediği gözlenmektedir. Ancak benzer yaşam memnuniyeti skoruna sahip bu OECD ülkeleri arasında da iş kalitesi göstergeleri önemli ölçüde farklılaşabilmektedir.

Korelasyon analizi sonucunda, yaşam memnuniyeti ile istihdam oranı, kazanç kalitesi, iş otonomisi ve öğrenme firsatları ve kariyer ilerleme firsatı arasında doğru yönlü; işsizlik riski ve çalışma süreleri inelastikliği arasında ters yönlü anlamlı bir korelasyon gözlenmiştir. Bu sonuç istihdam oranı, kazanç kalitesi, iş otonomisi ve öğrenme fırsatları ve kariyer ilerleme firsatındaki artışın yaşam memnuniyetini olumlu şekilde, işsizlik riski ve çalışma süreleri inelastikliğindeki artışın ise, olumsuz şekilde etkilediği anlamına gelmektedir. Çalışmadan elde edilen sonuçlar, işsizliğin yaşam memnuniyetini olumsuz etkilediğini (Green 2006; Clark ve Oswald 1994; Clark 2015) ve yine bir işe sahip olmanın yaşam memnuniyetini olumlu etkilediğini savunan Grün ve arkadaşlarının (2010) çalışmalarıyla paralellik göstermektedir.

Çoklu doğrusal regresyon analizinde istihdam oranındaki 1 birimlik artışın, OECD ülkelerinin yaşam memnuniyeti skorunu 0,027; kazanç kalitesindeki 1 
birimlik artışın 0,035; iş otonomisi ve öğrenme firsatlarındaki 1 birimlik artışın 0,018 ve kariyer ilerleme fursatındaki 1 birimlik artışın, 0,030 puan artırabileceği sonucuna ulaşılmıştır. Bu sonuçlar istihdamın yanı sıra, işyerinde kazanç kalitesi, iş otonomisi ve öğrenme firsatları ve kariyer ilerleme firsatlarının artırılmasının değişen oranlarda yaşam memnuniyetini olumlu yönde etkileyebileceği anlamına gelmektedir. Bu da, insanların işyerinde iş kalitesinden kaynaklanan eşitsizliklerden içsel hoşnutsuzluklarını sergileme eğiliminde olduğunu göstermektedir (OECD, 2014, s.80).

Yaşam memnuniyetinin önemli bir unsuru olan iş kalitesi sadece çalışanlar ve firmalar için değil, aynı zamanda politika yapıcılar için de önemli bir konudur. Çünkü iş kalitesi, insanların işyerinde ne kadar başarı gösterdiklerine dair bir barometre görevi görmektedir. Bu anlamda iş kalitesini artırmak için devlet, düşük gelirli çalışanların istihdam üzerinden alınan vergilerinin düşürülmesi ve toplu taşıma veya çocuk bakımı sübvansiyonları gibi bir takım politikalara başvurabilmektedir (Clark, 2015, s.3).

Son söz olarak, bu çalışmanın ulaştı̆̆ sonuçlar, verilerin niteliği ve örneklem büyüklüğü bakımından, buz dağının sadece görünen yüzünü yansıtmaktadır. Daha detaylı analizler için gelecek çalışmaların iş kalitesinin cinsiyet, yaş ve eğitim durumu gibi kişisel özellikleri de dikkate alarak, yaşam memnuniyetini derinlemesine incelemesi bu alandaki bilgi birikimini artıracaktır.

\footnotetext{
Hakem Değerlendirmesi: Dış bağımsız.

Çıkar Çatışması: Yazar çıkar çatışması bildirmemiştir.

Finansal Destek: Yazar bu çalışma için finansal destek almadığını beyan etmiştir.

Yazar Katkısı: Çalışma Konsepti/Tasarımı: A.G., S.G.; Veri Toplama: A.G.; Veri Analizi/Yorumlama: A.G.; Yazı Taslağı: A.G., S.G.; İçeriğin Eleştirel İncelemesi: A.G., S.G.; Son Onay ve Sorumluluk: A.G., S.G.

Peer-review: Externally peer-reviewed.

Conflict of Interest: The author has no conflict of interest to declare.

Grant Support: The author declared that this study has received no financial support.

Author Contributions: Conception/Design of study: A.G., S.G.; Data Acquisition: A.G.; Data Analysis/Interpretation: A.G.; Drafting Manuscript: A.G., S.G.; Critical Revision of Manuscript: A.G., S.G.; Final Approval and Accountability: A.G., S.G.
} 


\section{Kaynakça/References}

Anh, N., Nguyen, N. M., Mai, N. P., \& Nguyen, T.T. (2018). Job satisfaction in developing countries: An evidence from a matched employer-employee survey in Vietnam. Journal of Economic Studies, 46(1), 192-210. https://doi.org/10.1108/JES-04-2017-

Bowlby, G., Kuhnert, I., \& Van Der Valk, J., Chernyshev, I., Gaucaite Wittich, V., Boko, D. Vanek, J. (2010). Statistical measurement of quality of employment. Chapter I. In: Measuring Quality of Employment Country Pilot Reports (s.1-12). UNECE Task Force on the Measurement of Quality of Employment. Geneva.

Buhai, S., Cottini, E., \& Westergârd-Nielsen, N. (2008). The impact of workplace conditions on firm performance. Tinbergen Institute Discussion Paper TI.

Cazes, S., Hijzen, A., \& Saint-Martin A. (2016). Measuring and assessing job quality: The OECD job quality framework. OECD Social, Employment and Migration Working Papers, No. 174, OECD Publishing, Paris. http://dx.doi.org/10.1787/5jrp02kjw1mr-en.

Clark, A., \& Oswald, A. (1994). Unhappiness and unemployment. The Economic Journal, 104 (424), 648-659. https://doi.org/10.2307/2234639.

Clark, A. E. (2001). What really matters in a job? Hedonic measurement using quit data. Labour Economics 8(2), 223-242. https://doi.org/10.1016/S0927-5371(01)00031-8.

Clark, A. E. (2015). What makes a good job? Job quality and job satisfaction. IZA World of Labor, ISSN 2054-9571, Institute for the Study of Labor (IZA), Bonn, Iss. 215. http://dx.doi.org/10.15185/izawol.215.

Diener, E., \& Suh, E. (1997). Measuring quality of life: Economic, social, and subjective indicators. Social Indicators Research, 40, 189-216. https://doi. org/10.1023/A:1006859511756.

Diener, E., \& Suh, E. M. (1999). National differences in subjective well-being. In D. Kahneman, E. Diener, \& N. Schwarz (Eds.), Well-being: The Foundations of Hedonic Psychology (s.434-450). New York: Sage.

Diener, E., Suh, E. M., Lucas, R. E., \& Smith, H. L. (1999). Subjective well-being three decades of progress. Psychological Bulletin, 125, 276-302. https://doi. org/10.1037/0033-2909.125.2.276.

Diener, E. (2000). Subjective well-being: The science of happiness and a proposal for a national index. American Psychologist, 55, 34-43. https://doi.org/10.1037/0003066X.55.1.34.

Diener, E. and Tay, L. (2012). A scientific review of the remarkable benefits of happiness for successful and healthy living. Report of the Well-Being Working Group, Royal Government of Bhutan: Report to the United Nations General Assembly, Well-Being and Happiness: A New Development Paradigm, UN, NY.

Dooley, D., \& Prause, J. (2004). The social costs of underemployment: Inadequate employment as disguised unemployment. Cambridge University Press, Cambridge, The UK. 
Dumludağ, D. (2013). Life satisfaction and income comparison effects in Turkey. Social Indicators Research, 114, 1199-1210. https://doi.org/10.1007/s11205-012-0197-3.

Dumludağ, D., Gokdemir, O., \& Giray Yakut, S. (2016). Income comparison, collectivism and life satisfaction in Turkey. Quality \& Quantity, 50, 955-980. https:// doi.org/10.1007/s11135-015-0185-1.

Elliot, R. F. (1997). Karşılaştırmalı Çalışma Ekonomisi. Ankara Üniversitesi Yayınları, Yayin No:210, Ankara.

Eren, K.A. \& Aşıc1, A.A. (2017). The determinants of happiness in Turkey: Evidence from city-level data. J Happiness Stud., 18, 647-669. https://doi.org/10.1007/s10902016-9746-9.

Erhel, C., \& Guergoat-Larivière, M. (2010). Job quality and labour market performance. CEPS working Document NO. 330.

Eurofound. (2012). Trends in job quality in Europe. Publications Office of the European Union, Luxembourg.

Gitmez, A. S., \& Morcöl, G. (1994). Socio-economic status and life satisfaction in Turkey. Social Indicators Research, 31, 77-98. https://doi.org/10.1007/BF01086515.

Görmüş, A. (2021). Kısmi süreli işlerin kalitesi: Çoklu doğrusal regresyon modeli ile OECD ülkelerinden bulgular. Optimum Ekonomi ve Yönetim Bilimleri Dergisi, 8(2), 397-416. https://doi.org/10.17541/optimum.915213.

Green, F. (2006). Demanding work - the paradox of job quality in the affluent economy. Princeton: Princeton University Press.

Grün, C., Hauser, W., \& Rhein, T. (2010). Is any Job better than no job? Life satisfaction and re-employment. J. Labor Res. 31: 285-306. https://doi.org/10.1007/s12122-0109093-2.

Hall A. (2014). Life satisfaction, concept of. In: Michalos A.C. (Ed.) Encyclopedia of Quality of Life and Well-Being Research. Springer, Dordrecht. https://doi. org/10.1007/978-94-007-0753-5_1649.

Harrison, D. A., Newman, D. A., \& Roth, P. L. (2006). How important are job attitudes? Metaanalytic comparisons of integrative behavioral outcomes and time sequences. Academy of Management Journal, 49(2), 305-325. https://doi.org/10.5465/ AMJ.2006.20786077.

Harter, J., Hayes, T., \& Schmidt, F. (2002). Business-unit-level relationship between employee satisfaction, employee engagement, and business outcomes: A metaanalysis. Journal of Applied Psychology 87(2), 268-279. https://doi.org/10.1037/00219010.87.2.268.

Howell, R. T., \& Howell , C. J. (2008). The relation of economic status to subjective well-being in developing countries: A meta-analysis. Psychological Bulletin,134(4), $536-560$.

ILOstat (2021). Measuring the job quality: Difficult but necessary. Erişim adresi: https://ilostat.ilo.org/measuring-job-quality-difficult-but-necessary/. 
İslamoğlu, A. H. ve Alnıaçık, Ü. (2014). Sosyal bilimlerde araştırma yöntemleri, (4. Bs.) İstanbul: Beta Basım Yayım Dağıtım A.Ş.

Kalleberg, A., Reskin, B., \& Hudson, K. (2000). Bad jobs in America: Standard and nonstandard employment relations and job quality. American Sociological Review, 65(2), 256-278. http://dx.doi.org/10.2307/2657440.

Kalleberg, A., \& Vaisey, S. (2005). Pathways to good job: Perceived job quality among the machinists in North America. British Journal of Industrial Relations, 43(3), 431454. https://doi.org/10.1111/j.1467-8543.2005.00363.x.

Kauhanen, M., \& Nätti, J. (2015). Involuntary temporary and part-time work, job quality and well-being at work. Social Indicators Research, 120, 783-799. https://doi. org/10.1007/s11205-014-0617-7.

Keyes, C. L. M. (2006). Mental health in adolescence: Is America's youth flourishing? American Journal of Orthopsychiatry, 76, 395-402.

Kline, R. B. (2009). Becoming a behavioral science researcher: A guide to producing research that matters. New York: Guilford Press.

Kubiszewski, I., Zakariyya, N., Costanza, R., \& Jarvis, D. (2020). Resilience of selfreported life satisfaction: A case study of who conforms to set point theory in Australia. PLoS ONE, 15(8). https://doi.org/10.1371/journal. pone.0237161.

Kubiszewskia, I. Zakariyyab, N., \& Costanzaa, R. (2018). Objective and subjective indicators of life satisfaction in Australia: How well do people perceive what supports a good life. Ecological Economics, 154, 361-372. https://doi.org/10.1016/j. ecolecon.2018.08.017.

Küçüksille, E. (2014). Çoklu doğrusal regresyon modeli. İçinde: (Ed. Kalaycı Ş.) SPSS Uygulamalı Çok Değişkenli İstatistik Teknikleri, 6. Baskı, Ankara, Asil Yayın Dağıtım.

Lent, R., \& Brown, S. (2006). Integrating person and situation perspective on work satisfaction: A social cognitive view. Journal of Vocational Behavior, 69, 236-247. https://doi.org/10.1016/j.jvb.2006.02.006.

Lent, R., \& Brown, S. (2008). Social cognitive career theory and subjective wellbeing in the context of work. Journal of Career Assessment, 16, 6-21. https://doi. org/10.1177/1069072707305769.

Levin, K. A., \& Currie, C. (2014). Reliability and validity of an adapted version of the cantril ladder for use with adolescent samples. Social Indicators Research, 119, $1047-$ 1063. https://doi.org/10.1007/s11205-013-0507-4.

Lomax, R. G., \& Hahs-Vaughn, D. L. (2012). An introduction to statistical concepts (3rd ed.). New York: Taylors and Francis.

Lucas, R. E., Clark, A. E., Georgellis, Y. \& Diener, E. (2004). Unemployment alters the set point for life satisfaction. Psychological Science, 15(1), 8-13. https://doi.org/10.1111/ j.0963-7214.2004.01501002.x. 
Lüchinger, S., Meier, S., \& Stutzer, A. (2010), Why does unemployment hurt the employed? Evidence from the life satisfaction gap between the public and the private sector, Journal of Human Resources, 45(4), 998-1045.

OECD (2014). OECD Employment Outlook 2014. OECD Publishing. http://dx.doi. org/10.1787/empl_outlook-2014-en.

OECD (2016a). Society at a glance 2016 OECD social indicators. OECD Publishing, Paris. available at: http://dx.doi.org/10.1787/9789264261488-en.

OECD (2016b). How good is your job? Measuring and assessing job quality. OECD Brief. Erişim adresi: http://www.oecd.org/sdd/labour-stats/Job-quality-OECD.pdf.

OECD (2017). OECD employment outlook 2017. OECD Publishing. Paris. http://dx.doi. org/10.1787/empl_outlook-2017-en.

OECD Stat, (2021a). Job quality 2010-2015, Erişim adresi: https://stats.oecd.org/.

OECD Stat, (2021b). How's life? Well-being, Erişim adresi: https://stats.oecd.org/.

Ozben, S. (2013). Social skills, life satisfaction, and loneliness in Turkish university students. Social Behavior and Personality: an international journal (SBP Journal), 41(2), 203-214. https://doi.org/10.2224/sbp.2013.41.2.203.

Pavot, W., \& Diener, E. (2008). The satisfaction with life scale and the emerging construct of life satisfaction. The Journal of Positive Psychology, 3(2), 137-152, https://doi. org/10.1080/17439760701756946.

Sami, P., Sabri U., Ilyas, M., \& Amjad, Z. (2011). Organizational culture and its impact on the job satisfaction of the university teachers of lahore. International Journal of Business and Social Science, 2(24). 121-128.

Selim, S. (2008). Life satisfaction and happiness in Turkey. Social Indicators Research, 88, 531-562. https://doi.org/10.1007/s11205-007-9218-z.

Sousa, L., \& Lyubomirsky, S. (2001). Life satisfaction. In J. Worell (Ed.), Encylopedia of Women and Gender: Sex Similarities and Differences and the Impact of Society on Gender. 2, (s.667-676). San Diego, CA: Academic Press.

Tam, H. (2010). Characteristics of the underemployed and the overemployed in the UK. Economic \& Labour Market Review, 4(7), 8-20. https://doi.org/10.1057/elmr.2010.92.

Tilly, C. (1996). Half a job: Bad and good part-time jobs in a changing labor market. Philadelphia, PA: Temple University Press.

Toker, B. (2012). Life satisfaction among academicians: an empirical study on the universities of Turkey. Procedia - Social and Behavioral Sciences, 47, 190-195. https:// doi.org/10.1016/j.sbspro.2012.06.637.

Tranmer, M., Murphy, J., Elliot, M. ve Pampaka, M. (2020). Multiple linear regression (2nd Edition). Cathie Marsh Institute Working Paper 2020-01. Erişim adresi: https://hummedia.manchester.ac.uk/institutes/cmist/archive-publications/workingpapers/2020/2020-1-multiple-linear-regression.pdf.

United Nations (UN) (2010). Measuring quality of employment country pilot reports, Geneva. 
Warren, T., \& Lyonette, C. (2020). Ungrateful slaves? An examination of job quality and job satisfaction for male part-time workers in the UK. Br. J. Sociol., 71(3), 82-402. https://doi.org/10.1111/1468-4446.12741.

Whitman, D. S., Van Rooy, D. L., \& Viswesvaran, C. (2010). Satisfaction, citizenship behaviours, and performance in work units: A meta-analysis of collective construct relations, Personnel Psychology, 63, 41-81. https://doi.org/10.1111/j.1744-6570.2009.01162.x.

Yazıcıoğlu, İ., \& Kubilay N., (2017). Analysing the relationship between job satisfaction and life satisfaction in terms of demographic variables: An research in accommodation businesses. Journal of Business Management and Economic Research, 1(1), 39-48, https://doi.org/10.29226/jobmer.2017.3.

Zelenski, J. M., Murphy, S. A., \& Jenkins, D. A. (2008). The happy-productive worker thesis revisited. Journal of Happiness Studies, 9(4), 521-537, https://doi.org/10.1007/ s10902-008-9087-4. 
EK TABLO

OECD Verileri (2015 veya en güncel yıl)

\begin{tabular}{|c|c|c|c|c|c|c|c|c|}
\hline \multirow{3}{*}{ : } & \multirow[b]{2}{*}{ 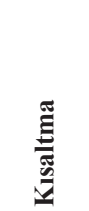 } & \multirow[b]{2}{*}{ 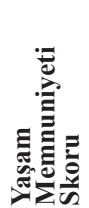 } & \multirow[b]{2}{*}{ 胥 } & \multirow[b]{2}{*}{ 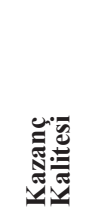 } & \multirow[b]{2}{*}{ 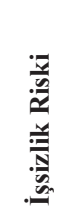 } & \multicolumn{3}{|c|}{ Çalışma Ortamı Kalitesi } \\
\hline & & & & & & 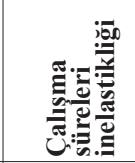 & 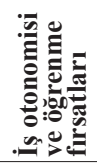 & 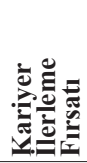 \\
\hline & & & $\%$ & $\$$ & $\%$ & $\%$ & $\%$ & $\%$ \\
\hline Avustralya & AUS & 7,3 & 61,07 & 22,68 & 6,45 & 29,59 & 26,56 & 24,92 \\
\hline Avusturya & AUT & 7 & 57,25 & 24,26 & 6,36 & 41,83 & 29,59 & 13,22 \\
\hline Belçika & BEL & 6,9 & 48,79 & 31,43 & 9,04 & 37,96 & 32,88 & 12,29 \\
\hline Kanada & CAN & 7,3 & 61,29 & 20,12 & 7,51 & & & \\
\hline Şili & $\mathrm{CHL}$ & 6,8 & 55,96 & 6,79 & 9,54 & 45,49 & 24,02 & 33,97 \\
\hline Çek Cumhuriyeti & $\mathrm{CZE}$ & 6,6 & 56,42 & 9,37 & 4,34 & 37,8 & 14,18 & 10,59 \\
\hline Danimarka & DNK & 7,5 & 57,54 & 30,99 & 6,53 & 30,11 & 48,62 & 22,52 \\
\hline Estonya & EST & 5,6 & 65,41 & $8,3 \mathrm{a}$ & 6,21 & 26,31 & 26,98 & 13,89 \\
\hline Finlandiya & FIN & 7,4 & 59,92 & 21,35 & 10,43 & 23,47 & 39,09 & 14,92 \\
\hline Fransa & FRA & 6,5 & 50,26 & $21,88 \mathrm{a}$ & 11,45 & 29,94 & 31,03 & 11,82 \\
\hline Almanya & DEU & 7 & 57,39 & 25,73 & 4,64 & 41,87 & 26,83 & 9,87 \\
\hline Yunanistan & GRC & 5,2 & 39,05 & 9,67 & 28,61 & 46,59 & 7,32 & 7,43 \\
\hline Macaristan & HUN & 5,3 & 55,86 & 7,57 & 6,33 & 37,25 & 11 & 16,35 \\
\hline İzlanda & ISL & 7,5 & 79,25 & 20,95 & 3,95 & 22,56 & 19,32 & 31,17 \\
\hline İrlanda & IRL & 6,9 & 55,69 & 17,53 & 9,08 & 39,79 & 19,67 & 18,77 \\
\hline İsrail & ISR & 7,4 & 60,73 & 8,21 & 7,26 & 41,7 & 25,45 & 36,64 \\
\hline İtalya & ITA & 5,9 & 43,14 & $18,85 \mathrm{a}$ & 12,42 & 33,24 & 16,25 & 5,46 \\
\hline Japonya & JPN & 5,9 & 57,57 & 17,5 & 3,39 & 55,65 & 13,1 & 8,93 \\
\hline Letonya & LVA & 5,8 & 54,14 & $6,72 a$ & 9,88 & 25,48 & 13,99 & 14,42 \\
\hline Lüksemburg & LUX & 6,8 & 55,98 & $30,54 \mathrm{a}$ & 6,46 & 33,14 & 33,28 & 16,31 \\
\hline Meksika & MEX & 6,5 & 57,22 & 4,74 & 4,58 & 52,74 & 25,85 & 39,43 \\
\hline Hollanda & NLD & 7,3 & 59,96 & $28,58 \mathrm{a}$ & 6,95 & 41,7 & 38,52 & 16,3 \\
\hline Yeni Zelanda & NZL & 7,4 & 65,01 & 17,28 & 5,65 & 19,42 & 30,64 & 30,75 \\
\hline Norveç & NOR & 7,5 & 62,19 & 27,77 & 4,93 & 21,75 & 49,55 & 16,18 \\
\hline Polonya & POL & 5,9 & 51,95 & $8,17 \mathrm{a}$ & 7,04 & 34,95 & 18,86 & 10,5 \\
\hline Portekiz & PRT & 5,1 & 51,30 & 8,98 & 12,86 & 37,6 & 9,14 & 12,05 \\
\hline $\begin{array}{l}\text { Slovak } \\
\text { Cumhuriyeti }\end{array}$ & SVK & 6,2 & 52,80 & 8,67 & 11,49 & 43,62 & 9,91 & 5,35 \\
\hline İspanya & ESP & 6,5 & 46,41 & $17,45 \mathrm{a}$ & 25,73 & 35,15 & 14,9 & 16,48 \\
\hline İsveç & SWE & 7,3 & 66,65 & $20,82 b$ & 7,86 & 30,08 & 51,07 & 10,28 \\
\hline İsviçre & $\mathrm{CHE}$ & 7,6 & 64,88 & $32,4 a$ & 4,8 & & & \\
\hline Türkiye & TUR & 5,6 & 46,01 & $7,38 \mathrm{a}$ & 11,66 & 31,49 & 9,52 & 27,81 \\
\hline Birleşik Krallık & GBR & 6,7 & 59,85 & 18,53 & 5,38 & 35,16 & 29,1 & 17,99 \\
\hline ABD & USA & 7,2 & 59,34 & 18,22 & 5,49 & 29,04 & 33,57 & 42,49 \\
\hline $\begin{array}{l}\text { OECD } \\
\text { Ortalamas1 }\end{array}$ & OECD & 6,6 & 56,11 & 17,46 & 8,62 & 35,69 & 24,99 & 18,24 \\
\hline
\end{tabular}

Kaynak: OECD Stat, 2021a, OECD, 2016a.

a 2014 y1lına ait veri. ${ }^{b} 2013$ y1lina ait veri. 
